\title{
The Progestin Receptor Interactome in the Female Mouse Hypothalamus: Interactions with Synaptic Proteins Are Isoform Specific and Ligand Dependent
}

\author{
[1 Kalpana D. Acharya, ${ }^{1}$ Sabin A. Nettles, ${ }^{1}$ Katherine J. Sellers, ${ }^{2}$ Dana D. Im, ${ }^{1}$ () Moriah Harling, ${ }^{1}$ \\ Cassandra Pattanayak, ${ }^{3}$ - Didem Vardar-Ulu, ${ }^{4}$ Cheryl F. Lichti, ${ }^{5}$ Shixia Huang, ${ }^{6}$ Dean P. Edwards, ${ }^{6}$ \\ (1)Deepak P. Srivastava, ${ }^{2}$ Larry Denner, ${ }^{7}$ and ${ }^{1}$ Marc J. Tetel ${ }^{1}$
}

\section{DOI:http://dx.doi.org/10.1523/ENEURO.0272-17.2017}

\begin{abstract}
${ }^{1}$ Neuroscience Program, Wellesley College, Wellesley, MA 02481, USA, ${ }^{2}$ Department of Basic and Clinical Neuroscience, Maurice Wohl Clinical Neurosciences Institute, Institute of Psychiatry, Psychology and Neuroscience, and MRC Centre for Neurodevelopmental Disorders, King's College London, London, UK, ${ }^{3}$ Quantitative Analysis Institute, Departments of Mathematics and Quantitative Reasoning, Wellesley College, Wellesley, MA 02481, USA, ${ }^{4}$ Chemistry Department, Boston University, Boston, MA 02215, USA, ${ }^{5}$ Department of Pathology and Immunology, Washington University School of Medicine, St. Louis, MO 63110, ${ }^{6}$ Department of Molecular and Cellular Biology, Department of Pathology and Immunology, and Dan L. Duncan Cancer Center, Baylor College of Medicine, Houston, TX 77030, USA, and ${ }^{7}$ Department of Internal Medicine, University of Texas Medical Branch, Galveston, TX 77555,
\end{abstract} USA

\begin{abstract}
Progestins bind to the progestin receptor (PR) isoforms, PR-A and PR-B, in brain to influence development, female reproduction, anxiety, and stress. Hormone-activated PRs associate with multiple proteins to form functional complexes. In the present study, proteins from female mouse hypothalamus that associate with PR were isolated using affinity pull-down assays with glutathione S-transferase-tagged mouse PR-A and PR-B. Using complementary proteomics approaches, reverse phase protein array (RPPA) and mass spectrometry, we identified hypothalamic proteins that interact with PR in a ligand-dependent and isoform-specific manner and were confirmed by Western blot. Synaptic proteins, including synapsin-I and synapsin-II, interacted with agonistbound PR isoforms, suggesting that both isoforms function in synaptic plasticity. In further support, synaptogyrinIII and synapsin-III associated with PR-A and PR-B, respectively. PR also interacted with kinases, including c-Src, mTOR, and MAPK1, confirming phosphorylation as an integral process in rapid effects of PR in the brain. Consistent with a role in transcriptional regulation, $\mathrm{PR}$ associated with transcription factors and coactivators in a ligand-specific and isoform-dependent manner. Interestingly, both PR isoforms associated with a key regulator of energy homeostasis, FoxO1, suggesting a novel role for PR in energy metabolism. Because many identified
\end{abstract}

\section{Significance Statement}

Progesterone binds to the progestin receptor (PR) isoforms, PR-A and PR-B, in the brain to profoundly influence female reproduction, brain development, neuroprotection, and stress. We combined mass spectrometry and reverse phase protein arrays to identify mouse hypothalamic proteins that function in synaptic plasticity, transcription, translation, and energy metabolism and interacted with PR in a liganddependent and isoform-specific manner. In addition, progesterone increased synaptic density in primary cortical neurons, suggesting a function for progesterone in synapse formation in cortical neurons. Taken together, these findings provide evidence for novel functions of PR in synaptic modulation and energy homeostasis to affect health and disease. 
proteins in this PR interactome are synaptic proteins, we tested the hypothesis that progestins function in synaptic plasticity. Indeed, progesterone enhanced synaptic density, by increasing synapsin-I-positive synapses, in rat primary cortical neuronal cultures. This novel combination of RPPA and mass spectrometry allowed identification of PR action in synaptic remodeling and energy homeostasis and reveals unique roles for progestins in brain function and disease.

Key words: Cortex; estrogen; progesterone; proteomics; synapse; synapsin

\section{Introduction}

Progestins, a class of steroid hormones, act in the brain to profoundly influence development (Beyer et al., 2002; Wagner, 2006); neuroprotection (Stein and Hoffman, 2003; Singh, 2006; Irwin et al., 2008; Su et al., 2012); reproductive behavior (Sinchak and Micevych, 2001; Blaustein, 2008); learning, memory, and cognition (Hull et al., 1980; Sandstrom and Williams, 2001; Wagner, 2006); and anxiety and stress (Mora et al., 1996; Blaustein and Ismail, 2013; Keyes et al., 2013; Uphouse et al., 2013). In addition, progestins have been implicated in a variety of human diseases, including neurodegeneration and breast cancer (Richer et al., 2002; Brinton et al., 2008; Obr and Edwards, 2012; Diep et al., 2015).

Progestins elicit many of their effects by binding to progestin receptors (PR), which exist as two isoforms in mammals, an N-terminally truncated PR-A and a fulllength PR-B (Tetel and Lange, 2009). Both isoforms share a C-terminal ligand binding domain, a DNA binding domain, and two transactivation domains (Horwitz et al., 1990; Kastner et al., 1990). Interestingly, a third transactivation domain exclusive to PR-B, and a PR-A specific inhibitory region, have been identified, allowing differential functions by the isoforms (Hovland et al., 1998). Isoform-specific transcriptional activation by PR has been observed in vitro and in vivo (Sartorius et al., 1994; Giangrande et al., 1997; Conneely et al., 2000; Cheng et al., 2001; Richer et al., 2002; Mulac-Jericevic et al., 2003). Isoform-specific knockout mice reveal that al-

Received August 2, 2017; accepted September 1, 2017; First published September 11, 2017.

Authors report no conflict of interest.

Author contributions: K.D.A., D.V.-U., D.P.S., L.D., and M.J.T. designed research; K.D.A., S.A.N., K.J.S., D.D.I., C.F.L., S.H., D.P.E., D.P.S., L.D., and M.J.T. performed research; K.D.A., S.A.N., K.J.S., M.H., C.P., C.F.L., S.H., D.P.E., D.P.S., L.D., and M.J.T. analyzed data; and K.D.A., D.P.E., D.P.S., L.D., and M.J.T. wrote the paper.

This work was funded by NIH R01 DK61935 (MJT), MRC MR/L021064/1 (DPS), Cancer Prevention \& Research Institute of Texas (CPRIT) Core Facility Support Award (RP170005), and $\mathrm{NCl}$ Cancer Center Support Grant to Antibody-based Proteomics Core/Shared Resource (P30CA125123; DPE and $\mathrm{SH})$.

Acknowledgments: We thank Fuli Jia, Kimberley Holloway, and Davis So of the Antibody-based Proteomics Core/Shared Resource at Baylor College of Medicine for their excellent technical assistance with RPPA assays and Dr. William Russell of the Proteomics Core of the University of Texas Medical Branch for helpful discussions.

Correspondence should be addressed to Kalpana D. Acharya, Neuroscience Program, Wellesley College, 106 Central St, Wellesley, MA 02481. E-mail: kacharya@wellesley.edu.

DOl:http://dx.doi.org/10.1523/ENEURO.0272-17.2017

Copyright () 2017 Acharya et al.

This is an open-access article distributed under the terms of the Creative Commons Attribution 4.0 International license, which permits unrestricted use, distribution and reproduction in any medium provided that the original work is properly attributed. though PR-A in the mouse hypothalamus is the primary mediator of female sexual behavior, both isoforms are required for the full behavioral response (Mani et al., 2006). In support, PR-A and PR-B are differentially expressed in the female mouse hypothalamus (Acharya et al., 2015).

PR associate with multiple proteins, including nuclear receptor coactivators, which stabilize the receptor complex and enhance transcription (Hill et al., 2012; Goswami et al., 2014; Simons et al., 2014). In the female mouse hypothalamus, the PR isoforms are differentially expressed with steroid receptor coactivator-1 (SRC-1, also named NCOA1) and SRC-2 (NCOA2; Acharya et al., 2015). In addition, SRC-1 and SRC-2 from hypothalamus associate with the PR isoforms in a ligand-dependent and isoform-specific manner (Molenda-Figueira et al., 2008; Yore et al., 2010) and modulate hormone-dependent gene expression and female sexual behavior (Apostolakis et al., 2002; Molenda et al., 2002; Molenda-Figueira et al., 2006). Taken together, these studies indicate that nuclear receptor coactivators are important in PR function in the brain.

PR act through both classic and nonclassic pathways in the brain and other progestin-responsive tissues. For example, in the hypothalamus, PR activation induces lordosis in female rodents through transcriptional regulation (Leonhardt et al., 2003; Molenda-Figueira et al., 2006) as well as nonclassic kinase activation (González-Flores et al., 2004; Mani et al., 2006). PRs are present in synapses (Waters et al., 2008; Mitterling et al., 2010) and rapidly alter dendritic spine densities in rat hippocampus (Woolley and McEwen, 1993; McEwen and Woolley, 1994), cortical neurons (Chen et al., 2009; Sanchez et al., 2013), and hypothalamus (Griffin et al., 2010).

Although we are gaining a better understanding of distinct functions of the PR isoforms in brain, little is known about the mechanisms involved. Therefore, to investigate the factors that could contribute to the differential function of the PR isoforms in brain, we have combined mass spectrometry (MS) and reverse phase protein array (RPPA) in a functional proteomic analysis to identify proteins from adult female mouse hypothalamus that interact with mouse PR-A and PR-B. In addition, given the identification of many synaptic proteins that interact with PR in the present study, we tested the hypothesis that progestins influence synaptic plasticity by increasing synapse formation in cortical neurons.

\section{Materials and Methods}

\section{Animals}

Female C57/BL6 mice were bred in the Wellesley College Animal Facility (Wellesley, MA). Mice were grouphoused (three to six/group) under a 12-h light/dark cycle. 
Food and water were available ad libitum. All animal procedures were approved by the Institutional Animal Care and Use Committee of Wellesley College and were conducted in accordance with the National Institutes of Health Guide for the Care and Use of Laboratory Animals.

\section{Tissue collection and preparation}

Mice (8 to 10 wks old) were bilaterally ovariectomized under $1.5 \%$ isoflurane. One week later, mice were killed by asphyxiation under $\mathrm{CO}_{2}$. Brains were quickly removed, and hypothalamic tissue was dissected using coordinates from the mouse brain atlas (Paxinos and Franklin, 2004), immediately frozen on dry ice, and stored at $-80^{\circ} \mathrm{C}$ until homogenization. Hypothalami from four to eight mice were pooled to generate each sample and lysed in lysis buffer containing $10 \mathrm{~mm}$ Tris, $10 \%$ glycerol, $400 \mathrm{~mm} \mathrm{NaCl}$, $1 \mathrm{~mm}$ dithiothreitol (DTT), and $1 \mathrm{~mm}$ EDTA (pH 7.4) with protease inhibitors (1:10 dilution, P2714, Sigma-Aldrich). Lysates were incubated on ice for $30 \mathrm{~min}$ followed by centrifugation at $13,200 \times g$ for $30 \mathrm{~min}$ at $4^{\circ} \mathrm{C}$. Supernatants containing proteins were stored at $-80^{\circ} \mathrm{C}$.

\section{Glutathione S-transferase-tagged mouse progestin receptors}

Mouse PR-B cDNA was cloned into the CMV-based mammalian cell expression plasmid pcDNAI (Invitrogen) by insertion into the PspHI/EcoRI site. Mouse PR-A cDNA was prepared by partial digest of mouse PR-B cDNA, ligated into the pBlueBacHis2B transfer plasmid, and inserted into the BamHI/EcoRV site of pcDNAI. pAcG2T baculovirus expression vector (BD Biosciences) was used for expression of PR-A and PR-B as fusion proteins, containing an $\mathrm{N}$-terminal glutathione S-transferase (GST) tag. Site-directed mutations were performed using QuikChange XL Site-directed Mutagenesis Kit (Stratagene). The mutated sites were used to ligate cDNAs of mouse PR-A and PR-B into the respective restriction sites of PAcG2T. Mouse $\mathrm{PR}-\mathrm{A}$ containing BamHI and EcoRI sites was ligated into the respective sites of the mutated pAcG2T. Similarly, mouse PR-B containing EcoRI and Notl sites was ligated into the respective sites of the mutated PAcG2T. Both DNA constructs were fully sequenced from the start of the GST to the end of the mouse PR subtype (Genewiz).

After the full sequences were confirmed, recombinant proteins containing full-length mouse PR-A or PR-B fused to a GST tag were expressed in Spodoptera frugiperda (Sf9) insect cells by the Baculovirus/Monoclonal Antibody Facility of the Baylor College of Medicine as described previously (Tetel et al., 1999; Molenda-Figueira et al., 2008; Yore et al., 2010). Insect cell cultures for GST-PR were incubated with saturating doses of $200 \mathrm{~nm}$ of the PR agonist R5020 or in the absence of PR ligand. Sf9 cell pellets were homogenized in buffer containing $10 \mathrm{~mm}$ Tris, $10 \%$ glycerol, $400 \mathrm{~mm} \mathrm{NaCl}, 1 \mathrm{mM}$ DTT, and $1 \mathrm{~mm}$ EDTA $(\mathrm{pH}$ 7.4) with protease inhibitors. Homogenates were incubated on ice for $30 \mathrm{~min}$, and then centrifuged at $13,200 \times g$ for $30 \mathrm{~min}$ at $4^{\circ} \mathrm{C}$. Supernatants containing proteins were stored at $-80^{\circ} \mathrm{C}$.

\section{GST-PR pull-down}

GST-PR pull-down assays were performed as described previously (Molenda-Figueira et al., 2008; Yore et al., 2010). Briefly, glutathione Sepharose 4B packed resin (50 $\mu \mathrm{L}, 0.05 \mathrm{mg} / \mathrm{mL}$, GE Healthcare) was added to siliconized centrifuge tubes and pretreated with ovalbu$\min (1 \mathrm{mg} / \mathrm{mL}$, Thermo Fisher Scientific) for $15 \mathrm{~min}$ on an end-over-end rotator at $4^{\circ} \mathrm{C}$. Resin was rinsed three times with TG buffer $(20 \mathrm{~mm}$ Tris- $\mathrm{HCl}$ and $10 \%$ glycerol) containing $1 \mathrm{~m}$ urea and $100 \mathrm{~mm} \mathrm{NaCl}$ (TG-NaCl-U, pH 8.0). GST-PRA or GST-PRB bound to the agonist R5020, or unliganded, were used for pull-downs. R5020 is a synthetic progestin that binds with a similar affinity to both PR-A and PR-B (Skafar, 1991; Carbajo et al., 1996). Equal amounts of recombinant mouse GST-PR suspended in TG buffer with $1 \mathrm{M}$ urea (TG-U, $\mathrm{pH}$ 8.0) were added to resin and incubated on a rotator at $4^{\circ} \mathrm{C}$ for $1 \mathrm{~h}$. After incubation, resin with immobilized GST-PR was washed four times with TG-NaCl-U (with reducing urea concentrations of $1,0.5,0.25$, and $0 \mathrm{M}$ ). Equal amounts of pooled hypothalamic homogenates were added to immobilized GST-PR and incubated on a rotator for $1 \mathrm{~h}$ at $4^{\circ} \mathrm{C}$. The resins were washed four times with $\mathrm{TG}-\mathrm{NaCl}$ (without urea).

Proteins bound to GST-PR resin were eluted in specific buffers for each of the analyses. For Western blots, samples were eluted by boiling for 5 min in $2 \times$ Laemmli sample buffer (Bio-Rad) with $35 \mathrm{~mm}$ DTT (Sigma-Aldrich) for $5 \mathrm{~min}$. For MS analysis, GST-PR and proteins bound to resin were eluted by incubating in $250 \mathrm{~mm}$ glutathione elution buffer (in $50 \mathrm{~mm}$ Tris- $\mathrm{HCl}, \mathrm{pH} 8.0$ ) at $4^{\circ} \mathrm{C}$ for $10 \mathrm{~min}$. Samples for RPPA analysis were boiled in SDS sample buffer (Invitrogen) with 2.5\% $\beta$-mercaptoethanol for $5 \mathrm{~min}$.

\section{Mass spectrometry analysis}

Pull-down assays for MS were performed with GSTPRA or GST-PRB, unliganded or bound to R5020. Tryptic peptides prepared as previously described (MolendaFigueira et al., 2008) for each receptor type and ligand condition were block-randomized and analyzed in triplicate (Oberg and Vitek, 2009) by nano-LC-MS/MS using a nano-LC chromatography system (UltiMate 3000 RSLCnano, Dionex), coupled online to a Thermo Orbitrap Fusion mass spectrometer (Thermo Fisher Scientific) through a nanospray ion source (Thermo Fisher Scientific). Chromatographic columns were made from $75-\mu \mathrm{m}$-ID polyimidecoated fused silica capillary (Polymicro Technologies) packed with $5 \mu \mathrm{m}$ Zorbax SB-C18 reversed-phase packing (Agilent) to a length of $10 \mathrm{~cm}$ by using a Pressure Injection Cell (NextAdvance). The trap column was prepared in the same manner but to a length of $1 \mathrm{~cm}$. After equilibrating the column in $98 \%$ solvent $A(0.1 \%$ formic acid in water) and $2 \%$ solvent $B(0.1 \%$ formic acid in acetonitrile), the samples ( $3 \mu \mathrm{L}$ in solvent A) were injected onto the trap column and eluted ( $400 \mathrm{~nL} / \mathrm{min}$ ) by gradient elution onto the $\mathrm{C} 18$ column as follows: isocratic at $2 \% \mathrm{~B}$, 0-5 min; $2 \%$ to $32 \%$ B, 5-49 min; $32 \%$ to $90 \%$ B, $49-50$ min; isocratic at $90 \% \mathrm{~B}, 50-54.5 \mathrm{~min} ; 90 \%$ to $2 \% \mathrm{~B}$, $54.5-55 \mathrm{~min}$; and isocratic at $2 \% \mathrm{~B}, 55-60 \mathrm{~min}$. All LC$\mathrm{MS} / \mathrm{MS}$ data were acquired using XCalibur, version 2.1.0 
(Thermo Fisher Scientific) in positive ion mode using a top speed data-dependent acquisition method with a 2-s cycle time. The survey scans $(\mathrm{m} / \mathrm{z} 350-1600)$ were acquired in the Orbitrap at 120,000 resolution (at $\mathrm{m} / \mathrm{z} 400$ ) in profile mode, with a maximum injection time of $50 \mathrm{~ms}$ and an automatic gain control (AGC) target of 400,000 ions. The $\mathrm{S}$-lens RF level was set to 60 . Isolation was performed in the quadrupole with a 1.6-Da isolation window, and CID MS/MS acquisition was performed in profile mode in the ion trap using rapid scan rate, with the following settings: parent threshold, 10,000; isolation width, 1.6 Da; normalized collision energy, 35\%; maximum injection time, 150 ms; and AGC target, 10,000 ions. Monoisotopic precursor selection and charge state filtering were on, with charge states 2-4 included. Dynamic exclusion was used to remove selected precursor ions for $60 \mathrm{~s}$ after acquisition of one MS/MS spectrum.

\section{Proteomic data analysis of MS samples}

All data files were searched against a Uniprot mouse database (June 2014 version, 16,728 proteins), appended with the Common Repository of Adventitious Proteins contaminant database using PEAKS (Ma et al., 2003; Han et al., 2004, 2011; Zhang et al., 2012). Searches were performed with a parent ion tolerance of $10 \mathrm{ppm}$, fragment ion tolerance of $0.80 \mathrm{Da}$, fixed modification of carbamidomethyl (C), and variable modifications of oxidation (M) and phosphorylation (STY). Trypsin was specified as the enzyme, allowing for two missed cleavages and one nonspecific cleavage. False discovery rate (FDR) estimation was allowed. The resulting peptide-spectrum matches $>1 \%$ FDR were used to generate a spectral library for subsequent quantitative analysis. Data files for each pair of samples were imported into Skyline (MacLean et al., 2010) for label-free quantitative analysis (Schilling et al., 2012). After manual verification of all peaks, triplicate peptide intensities were used to calculate fold changes and $p$-values.

\section{Reverse phase protein array analysis}

Hypothalamic tissue from adult female mice $(n=32)$ was pooled into four different groups. Similar to MS, RPPA assays were performed using pull-downs with GST-PRA and GST-PRB bound to R5020 or unliganded. RPPA assays were conducted as described previously (Chang et al., 2015) with the following modifications. Proteins associating with GST-PR bound to resins were eluted in $2 \times$ Tris-glycine SDS buffer with $2.5 \% \beta$-mercaptoethanol and mixed with modified Tissue Protein Extraction Reagent (Pierce and Xu, 2010) and a cocktail of protease and phosphatase inhibitors (Roche Life Science; Chang et al., 2015). A 2470 Arrayer (Aushon BioSystems) with a 40-pin $(185 \mu \mathrm{m})$ configuration was used to spot samples and control lysates onto nitrocellulose-coated slides (Grace Bio-labs) using an array format of 960 lysates/slide (2880 spots/slide). The slides were processed as described previously (Chang et al., 2015) and probed with a set of 212 antibodies (Table 1) against 140 total proteins and 72 proteins phosphorylated on specific sites using an automated slide stainer, Autolink 48 (Dako). Each slide was incubated with one specific primary antibody.
Negative control slides were incubated with antibody diluent instead of primary antibody. Primary antibody binding was detected using a biotinylated secondary antibody followed by streptavidin-conjugated IRDye680 fluorophore (LI-COR Biosciences). The total protein content of each spotted lysate was assessed by fluorescent staining with Sypro Ruby Protein Blot Stain according to the manufacturer's instructions (Invitrogen).

Fluorescence-labeled slides were scanned on a $\mathrm{Ge}-$ nePix 4400 AL scanner. Each slide, along with its accompanying negative control slide, was scanned at an appropriate photomultiplier tube to obtain optimal signal for this specific set of samples. The images were analyzed with GenePix Pro 7.0 (Molecular Devices). Total fluorescence signal intensities for each spot were obtained after subtraction of the local background signal for each slide and were then normalized for variation in total protein, background, and nonspecific labeling using a groupbased normalization method as described (Chang et al., 2015). Each image, along with its normalized data, was evaluated for quality through manual inspection and comparison with control samples. Specific fluorescence intensity signals of 50 units or less was taken as assay cutoff for a positive reaction, resulting in 195 remaining proteins, of the 212 (Table 1), to be analyzed.

\section{Analysis of data from RPPA assays}

After data were normalized to PR signal in the assay or to target protein input, it was determined that normalizing to PR produced the most consistent results. The effects of receptor type and hormone treatment were analyzed via two-way ANOVA using $R$. We identified proteins with FDR-adjusted $p$-values $<0.05$. For this subset of identified proteins, relative fold changes between the liganded and unliganded receptor were calculated for each isoform. For proteins displaying a positive interaction with the liganded PR, a two-fold change was used as a cutoff. For proteins showing a positive association with the unliganded PR, further stringency was maintained by setting a higher threshold of three-fold change, as with the MS data.

\section{Western blot analysis}

Western blot analyses were performed on representative proteins: synapsin-I and synapsin-II (MS-identified) and SRC-1, SRC-2, FoxO1, MED12, c-Fos, and c-Jun (RPPA-identified) to validate findings from the MS and RPPA analyses. Western blots were conducted as described previously (Bless et al., 2014) with the modifications indicated below. For independent validation of the ligand-dependent interaction of PR with hypothalamic SRC-1 and SRC-2 determined by RPPA, protein homogenates from female mouse hypothalamus $(n=6,5$ mice per group) were prepared as described above. Pull-down samples were probed for SRC-1 and SRC-2 using a rabbit polyclonal antibody to 350-690 amino acids (aa) of human SRC-1 (1:250, \#sc-8995, Santa Cruz, RRID:AB_2235896) and a rabbit polyclonal antibody to human SRC-2 (1:750, \#PA186392, Fisher Scientific, RRID:AB_2103955), respectively. MED12, c-Fos and C-Jun were probed with rabbit polyclonal antibodies MED12 (1:200, \#ab70842, Abcam), 
Table 1. List of antibodies used for RPPA analysis

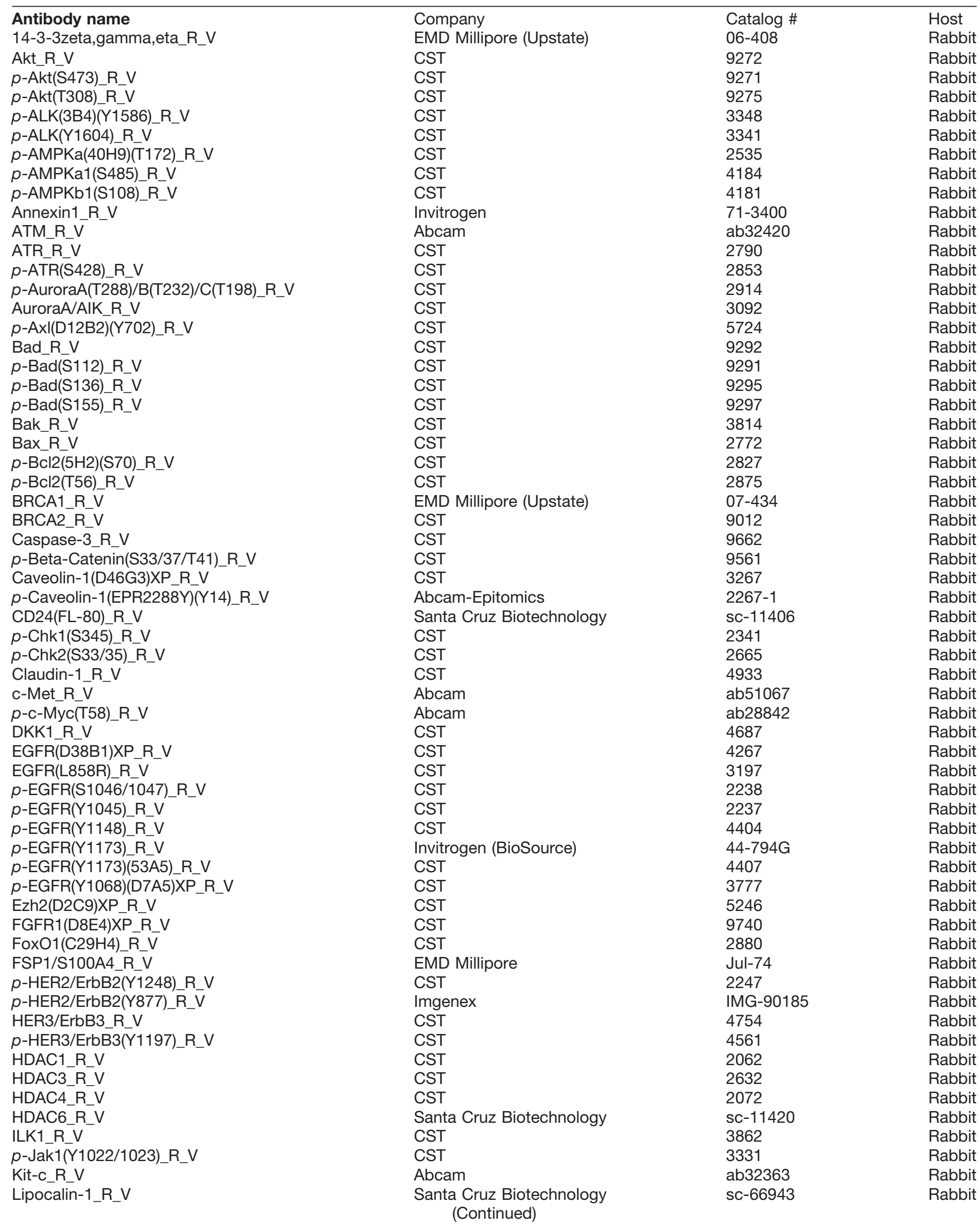


Table 1. Continued

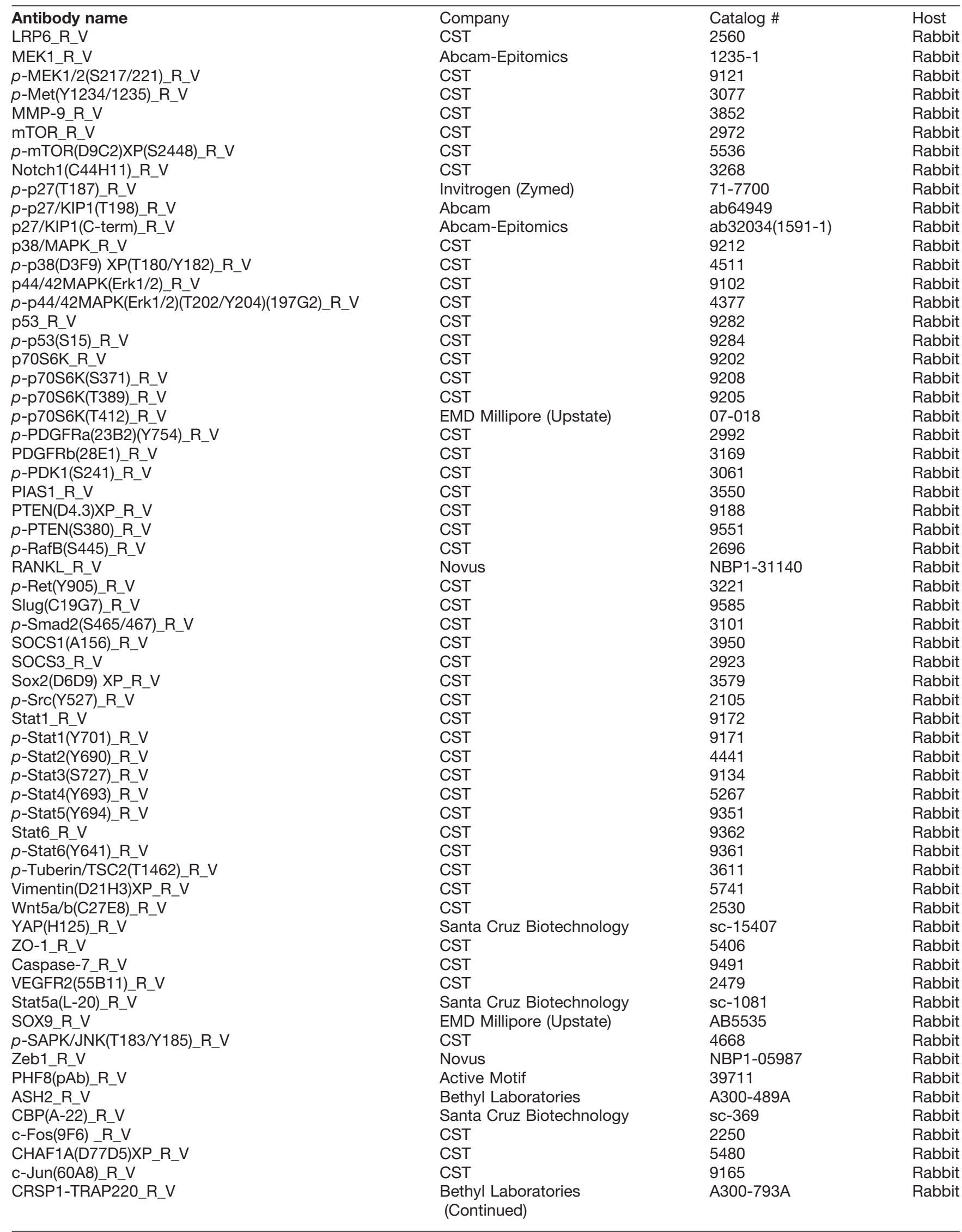


Table 1. Continued

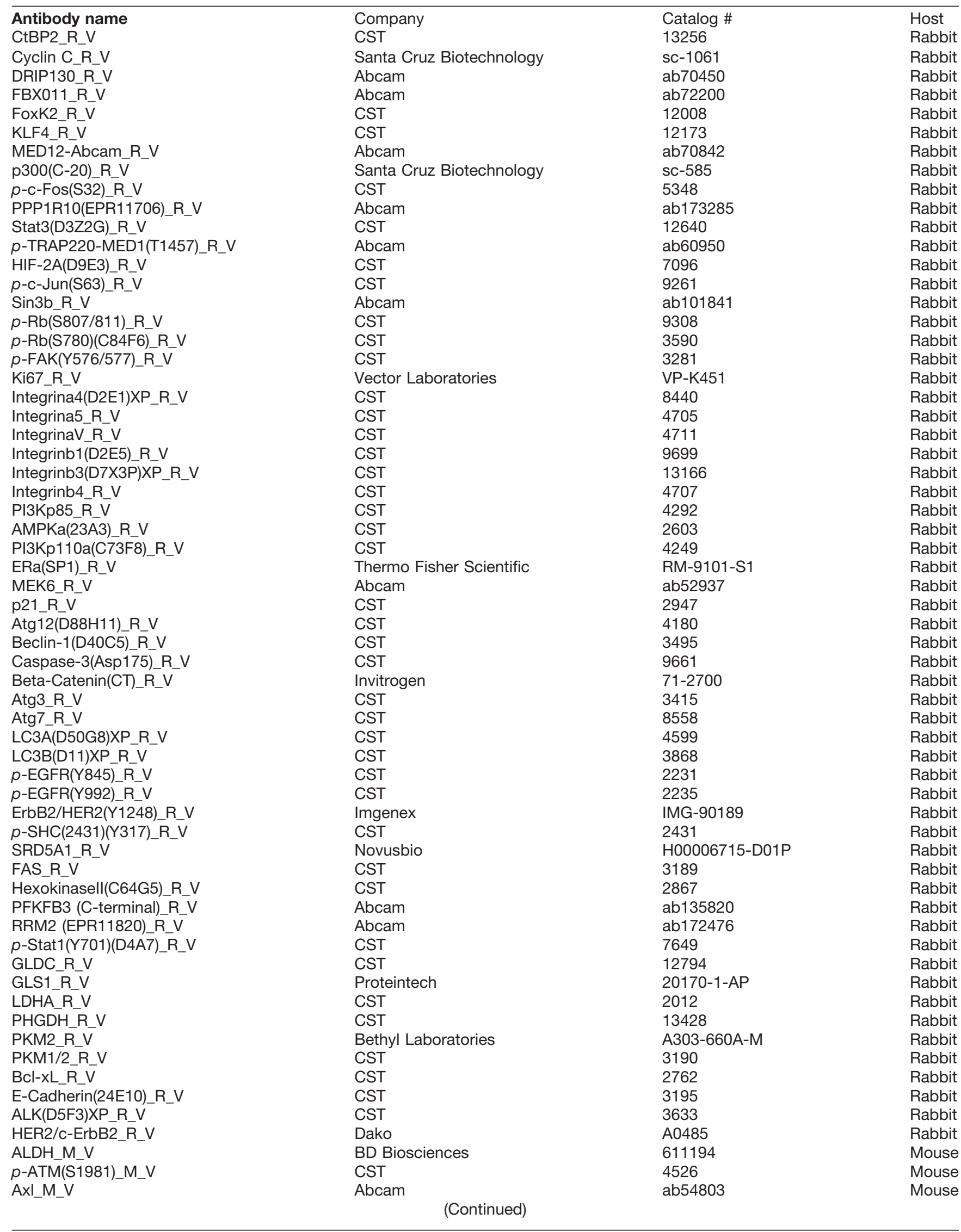


Table 1. Continued

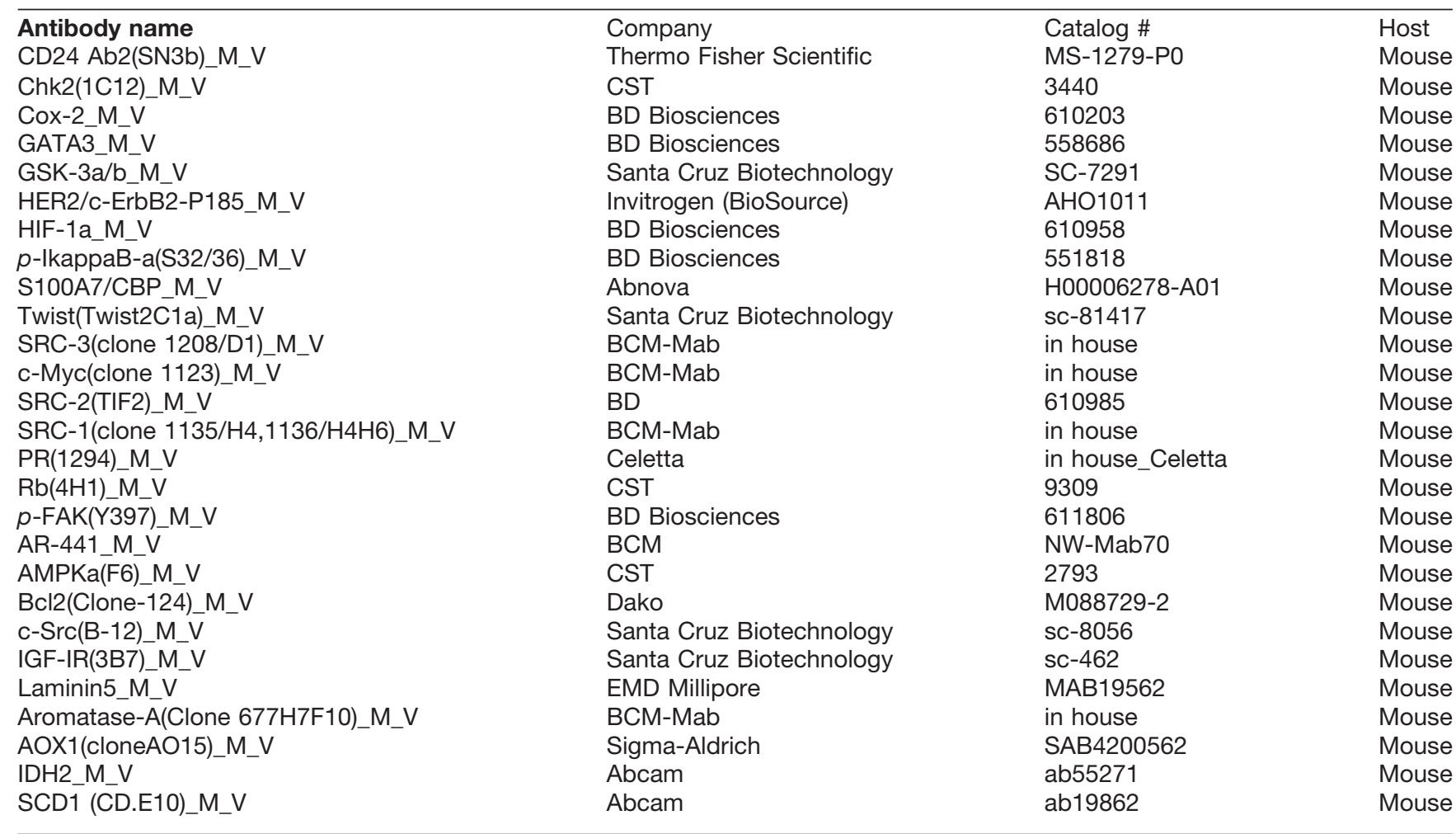

Host species for the antibodies and validation status are reported. R, rabbit; M, mouse and V, validated.

c-Fos (1:200, \#5348, Cell Signaling Technology), and C-Jun (1:200, \#9261, Cell Signaling Technology), respectively. Fluorescently labeled donkey anti-goat AF488 and donkey anti-rabbit AF647 were used for detection of SRC-1 and SRC-2 (1:10,000, Invitrogen), respectively. Immunoreactive bands were detected and relative optical densities were quantified using a GelDoc Imager and Image Lab Software (Bio-Rad). Two-way ANOVA followed by Tukey's honestly significant difference was used (SPSS v.21) to examine the effect of ligand and receptor type. We identified differences with Tukey-adjusted $p$-values $<0.05$. In addition, validation of MS findings of synapsin-I and synapsin-II by Western blot was conducted using a rabbit polyclonal antibody to synapsin-I (1:500, \#ab1543, Millipore, RRID:AB_2200400) and a mouse monoclonal antibody to synapsin-II $(0.3 \mu \mathrm{g} / \mathrm{mL}$, \#mabn1573, Millipore). Secondary antibodies donkey anti-rabbit AF647 and donkey anti-mouse AF488 (1:10,000, Invitrogen) were used for synapsin-I and synapsin-II, respectively.

In confirmation of findings by RPPA, interaction of PR with FoxO1 was analyzed by Western blot using a rabbit polyclonal FoxO1 antibody (1:250, \#2880, CST, RRID: $A B$ 2106495), the same as used for RPPA, followed by a donkey anti-rabbit AF647 secondary antibody $(1: 10,000$, Invitrogen). For the detection of mouse GST-PR, a mouse monoclonal antibody directed against the $\mathrm{N}$-terminal 165534 aa of human PR-A and PR-B (PR 1294, $0.5 \mu \mathrm{g} / \mathrm{mL}$ ), followed by a donkey anti-mouse AF488 secondary antibody (1:10,000, Invitrogen), was used.

\section{Neuronal cultures}

Primary cortical neuronal cultures (mixed sex) were prepared from Sprague-Dawley rat E18 embryos as described previously (Srivastava et al., 2011). These cortical cultures display mature neuronal morphology (extensive arborizations and dendritic spines) and electrophysiological and cellular responses to synaptic activity, consistent with those seen in in vivo/ex vivo studies of mature neurons (Xie et al., 2007; Srivastava et al., 2012). Because our MS and RPPA data were collected from mature brain, cortical neurons, which recapitulate mature neuronal characteristics (Xie et al., 2007; Srivastava et al., 2012), were used in these studies.

Animals were habituated for $3 \mathrm{~d}$ before experimental procedures, compliant with the Home Office Animals (Scientific Procedures) Act, UK, 1986. Dissociated cells were plated onto 18-mm glass coverslips (no. 1.5; 0117580, Marienfeld-Superior), coated with poly-D-lysine $(0.2 \mathrm{mg} /$ $\mathrm{ml}$, Sigma-Aldrich), at a density of $3 \times 10^{5} /$ well equal to $857 / \mathrm{mm}^{2}$ and cultured in feeding medium: neurobasal medium (21103049) supplemented with 2\% B27 (17504044), $0.5 \mathrm{~mm}$ glutamine (25030024), and 1\% penicillin:streptomycin (15070063; all reagents from Invitrogen). Neuron cultures were maintained in the presence of $200 \mu \mathrm{M} \mathrm{D}, \mathrm{L}-$ amino-phosphonovalerate (D,L-APV, ab120004, Abcam) beginning on $4 \mathrm{~d}$ in vitro (DIV 4 ) to maintain neuronal health for long-term culturing and reduce cell death due to excessive $\mathrm{Ca}^{2+}$ cytotoxicity via overactive NMDA receptors (Srivastava et al., 2011). Half-medium changes were performed twice weekly until the desired age (DIV 23-25). 


\section{Pharmacological treatment of neuronal cultures}

All pharmacological treatments were performed on DIV 25-30 primary cortical neuronal cultures. Treatments were conducted in feeding medium: neurobasal medium (21103049) supplemented with 2\% B27, $0.5 \mathrm{~mm}$ glutamine, and $1 \%$ penicillin:streptomycin in the presence of $200 \mu \mathrm{M}$ D,L-APV. Progesterone (P4; Sigma-Aldrich, P6149) was dissolved in ethanol to a concentration of $31.8 \mathrm{~mm}$, and $17 \beta$-estradiol (E2) was dissolved in dimethylsulfoxide to a final concentration of $1 \mathrm{~mm}$. Both compounds were serially diluted to a $10 \times$ working concentration in feeding medium and applied directly to neuronal cultures. Final concentrations of P4 and E2 were $1 \mathrm{~nm}$. Final concentration of solvent was $<0.01 \%$ : vehicle control was made up of solvent lacking compound, diluted as test compounds. Neuronal cultures were treated for $24 \mathrm{~h}$, washed in PBS, and fixed in $4 \%$ formaldehyde $/ 4 \%$ sucrose PBS for 10 min at room temperature followed by incubation in methanol prechilled to $-20^{\circ} \mathrm{C}$ for $10 \mathrm{~min}$ at $4^{\circ} \mathrm{C}$. Fixed neuronal cultures were then permeabilized and blocked simultaneously ( $2 \%$ normal goat serum, 5425 S, Sigma-Aldrich, and $0.2 \%$ Triton $X-100$ ) before incubation with the following primary antibodies overnight: PSD95 mouse monoclonal antibody (1:1000; clone K28/43; \#73-028, NeuroMab, RRID:AB_10698024), synapsin-I rabbit polyclonal antibody (1:200; \#5297, Cell Signaling Technologies), and MAP2 chicken polyclonal antibody (1:2000; \#AB104896, Abcam). Cultures were subsequently incubated with Alexa Fluor anti-rabbit 488, anti-mouse 568, and antichicken 633 secondary antibodies (1:750; Invitrogen) the following day for $1 \mathrm{~h}$ at room temperature (Srivastava et al., 2011).

\section{Quantitative and statistical analysis of immunofluorescence}

Confocal images of neurons were acquired with a Nikon A1-R confocal microscope using a $60 \times$ oil-immersion objective (NA 1.4; Nikon) as a z-series, $z$-step set to 0.5 $\mu \mathrm{m}$. Two-dimensional maximum-projection reconstructions of images were generated, and morphometric analysis (puncta number and intensity) was conducted using MetaMorph software (Universal Imaging Corporation; Srivastava et al., 2011). Analyses of puncta were performed on spines from at least two dendrites (secondary or tertiary branches), totaling $100 \mu \mathrm{m}$, from each neuron. The linear density of each synaptic protein cluster was measured automatically using MetaMorph (Srivastava et al., 2011). Synaptic puncta were defined as synapsin-I puncta that contained PSD95 immunofluorescence greater than background; background fluorescence was the average background intensity from five regions of interest plus two standard deviations (Glynn and McAllister, 2006). Cultures that were directly compared were stained simultaneously and imaged with the same acquisition parameters. For each condition, 10-16 neurons from at least 3 separate experiments were used. Experiments were conducted blind to condition and on sister cultures.

All statistical analyses were performed in GraphPad. Differences in quantitative immunofluorescence were identified by a one-way ANOVA with Tukey correction for multiple comparisons. Error bars represent the standard error of the mean.

\section{Results}

\section{Mass spectrometry}

To detect proteins from female mouse hypothalamus that associated with mouse PR in the presence or absence of hormone, MS analysis was performed on pulldown samples using GST-tagged PR. This unbiased approach identified many hypothalamic proteins that interact with one or both PR isoforms in a ligand-dependent manner (Tables 2 and 2-1). MS-identified proteins were categorized into the following groups based on their functions: (a) synaptic structure and function, (b) signal transduction, (c) transcription, (d) translation, and (e) metabolism. The proteins associated with synaptic structure and function was the largest group, containing $61 \%$ (20 of 35 ) of the MS-identified proteins that interacted with ligand-bound PR. Subsets of these synaptic proteins associated with PR-A only (9 proteins), PR-B only (7), or both isoforms (4) in a ligand-dependent manner, strongly indicating a function for both PR isoforms in synaptic physiology. More than $18 \%$ (6 of 35 ) of the identified PR-interacting proteins are transcriptional regulators, with two-thirds associating with PR-B only and the remaining one-third associating with PR-A only. Proteins involved in signal transduction, including kinases, comprised 9\% (3 of 35 ) of the MS-identified proteins that associated with PR in the presence of ligand. We also identified the translational regulators $40 \mathrm{~S}$ ribosomal protein S9 and $26 \mathrm{~S}$ protease regulatory subunit $6 \mathrm{~A}$ that associated only with PR-B in the presence of R5020. On the other hand, proteins with a role in cellular metabolism identified by MS interacted with liganded PR-A only (Table 2). Finally, consistent with previous studies (Bagchi et al., 1991; Johnson and Toft, 1994), a large number of additional proteins interacted with unliganded PR-A, PR-B, or both (Table 2-1).

To validate findings by MS, pull-down samples were analyzed by Western blot for select synaptic proteins, the largest functional group identified in the MS analysis. Western blot results showed an increased interaction of synapsin-la and synapsin-lb with both PR-A and PR-B in the presence of R5020 compared with no ligand (Fig. 1). Similarly, the synapsin-II isoforms, synapsin-Ila and synapsin-Ilb, interacted with PR-A and PR-B in a liganddependent manner, further extending the MS findings.

\section{RPPA}

To further explore the interactions of proteins from mouse hypothalamus with PR, we used RPPA, which provides a targeted approach and allows identification of phospho-proteins as markers of protein activity. RPPA analysis identified multiple proteins that interacted with mouse PR in a ligand-dependent and isoform-specific manner (Tables 3 and 3-1). In support of the present MS results, many of the identified proteins that associated with liganded PR were transcriptional regulators (Table 3). Additional proteins identified by RPPA that were not de- 
Table 2. Proteins from mouse hypothalamus, identified by MS analysis, associate with mouse PR in a ligand-dependent manner

\begin{tabular}{|c|c|c|c|c|}
\hline Synaptic structure and function & UniProt symbol & Uniprot ID & $\begin{array}{l}\text { PR-A (R5020/no } \\
\text { ligand) }\end{array}$ & $\begin{array}{l}\text { PR-B (R5020/no } \\
\text { ligand) }\end{array}$ \\
\hline Synapsin-I & SYN1 & O88935 & + & + \\
\hline Synapsin-II & SYN2 & Q64332 & + & + \\
\hline Synapsin-III & SYN3 & Q8JZP2 & & + \\
\hline Synaptogyrin-III & SNG3 & Q8R191 & + & \\
\hline$\alpha$-Synuclein & SYUA & 055042 & & + \\
\hline Septin-5 & SEPTM5 & Q9Z2Q6 & & + \\
\hline Desmoglein-4 & Desmoglein-4 & Q7TMD7 & + & \\
\hline Desmoplakin & DESP & E9Q557 & + & \\
\hline Junction plakoglobin & PLAK & Q02257 & + & \\
\hline Leucine-rich repeat-containing protein 15 & LGR4 & A2ARI4 & + & \\
\hline Hemoglobin subunit $\beta-1$ & HBB1 & P02088 & + & \\
\hline$\beta$-Actin-like protein 2 & ACTBL & Q8BFZ3 & & + \\
\hline Tubulin $\alpha-1 \mathrm{~A}$ chain & TBA1A & P68369 & & + \\
\hline Tubulin $\alpha-1 \mathrm{~B}$ chain & TBA1B & P05213 & & + \\
\hline Tubulin $\beta-2 A$ chain & TBB2A & Q7TMM9 & + & + \\
\hline Tubulin $\beta-3$ chain & TBB3 & Q9ERD7 & + & \\
\hline Tubulin $\beta-4 \mathrm{~A}$ chain & TBB4A & Q9D6F9 & + & \\
\hline Tubulin $\beta-4 \mathrm{~B}$ chain & TBB4B & P68372 & + & \\
\hline Tubulin $\beta-5$ chain & TBB5 & P99024 & + & + \\
\hline Tubulin $\beta-6$ chain & TBB6 & Q922F4 & & + \\
\hline \multicolumn{5}{|l|}{ Signal transduction } \\
\hline Mitogen-activated protein kinase 1 & MK01 & P63085 & & + \\
\hline $14-3-3$ protein $\zeta / \delta$ & $1433 Z$ & P63101 & & + \\
\hline Rab GDP dissociation inhibitor $\beta$ & GDIB & Q61598 & & + \\
\hline \multicolumn{5}{|l|}{ Transcription } \\
\hline Elongation factor $1 \beta$ & TIF1B & Q62318 & + & \\
\hline Histone $\mathrm{H} 4$ & $\mathrm{H} 4$ & P62806 & + & \\
\hline Brain acid soluble protein 1 & A4 & P12023 & & + \\
\hline Heterogeneous nuclear ribonucleoprotein D-like & HNRDL & Q9Z130 & & + \\
\hline Heterogeneous nuclear ribonucleoprotein U-like protein 1 & HNRL1 & Q8VDM6 & & + \\
\hline Probable ATP-dependent RNA helicase DDX5 & DDX5 & Q61656 & & + \\
\hline \multicolumn{5}{|l|}{ Translation } \\
\hline $26 \mathrm{~S}$ protease regulatory subunit $6 \mathrm{~A}$ & PRS6A & 088685 & & + \\
\hline 40S ribosomal protein S9 & RS9 & Q6ZWN5 & & + \\
\hline \multicolumn{5}{|l|}{ Metabolism } \\
\hline Creatine kinase B-type & KCRB & Q04447 & + & \\
\hline Phytanoyl-CoA hydroxylase-interacting protein-like & PHIPL & Q8BGT8 & + & \\
\hline
\end{tabular}

Proteins associate with PR with R5020/no ligand at a ratio $\geq 2$ and $p<0.05$. Table 2-1 shows proteins identified by MS that associate with PR in the absence of ligand.

tected by MS have known roles in signal transduction or metabolism; a subset were phosphorylated forms of signaling proteins, including src kinase (Table 3).

Two nuclear receptor coactivators, SRC-1 and SRC-2, known to be involved in PR expression and function in brain (Molenda et al., 2002; Molenda-Figueira et al., 2006, 2008; Yore et al., 2010; Acharya et al., 2015), were also detected by RPPA to interact with PR-A and PR-B in the presence of R5020 compared with no ligand. Liganddependent interactions with SRC-1 and SRC-2 were further confirmed by Western blot analysis (Fig. 2). Two-way ANOVA on SRC-1 relative intensity showed an effect of ligand $\left(F=14.56, p=10.0 \times 10^{-4}\right)$ such that SRC-1 interacted with PR-A and PR-B in the presence of R5020 compared with no ligand. Similarly, SRC-2 associated with both $\mathrm{PR}$ isoforms when bound to R5020 $(F=21.65$, $p=3.0 \times 10^{-5}$ ) compared with no ligand. There were differences between receptor subtypes on interaction with either SRC-1 or SRC-2 (Fig. 2). Interestingly, the majority of proteins that function as transcriptional regulators, as identified by RPPA, interacted with PR-A only (Table 3). Furthermore, proteins involved in signal transduction identified by RPPA interacted with PR-A, but not $\mathrm{PR}-\mathrm{B}$, in the presence of agonist (Table 3). A transcription factor with a role in energy metabolism, FoxO1, was also identified to interact with both PR-A and PR-B. This interaction of FoxO1 with PR was further validated by Western blot (Fig. 3). Confirmation of C-Fos, C-Jun, and MED12, identified by RPPA, by Western blot was not possible because the signal intensities of these proteins by Western were not strong enough to be analyzed, most likely because of the decreased sensitivity of Western blot compared with RPPA. Two other proteins identified by MS to interact with liganded PR, MAP kinase 1 and 14-3-3 protein $\zeta / \delta$, were not found to associate with PR in a ligand-dependent manner by RPPA, likely because of differences in sensitivities for specific proteins between the two techniques. 

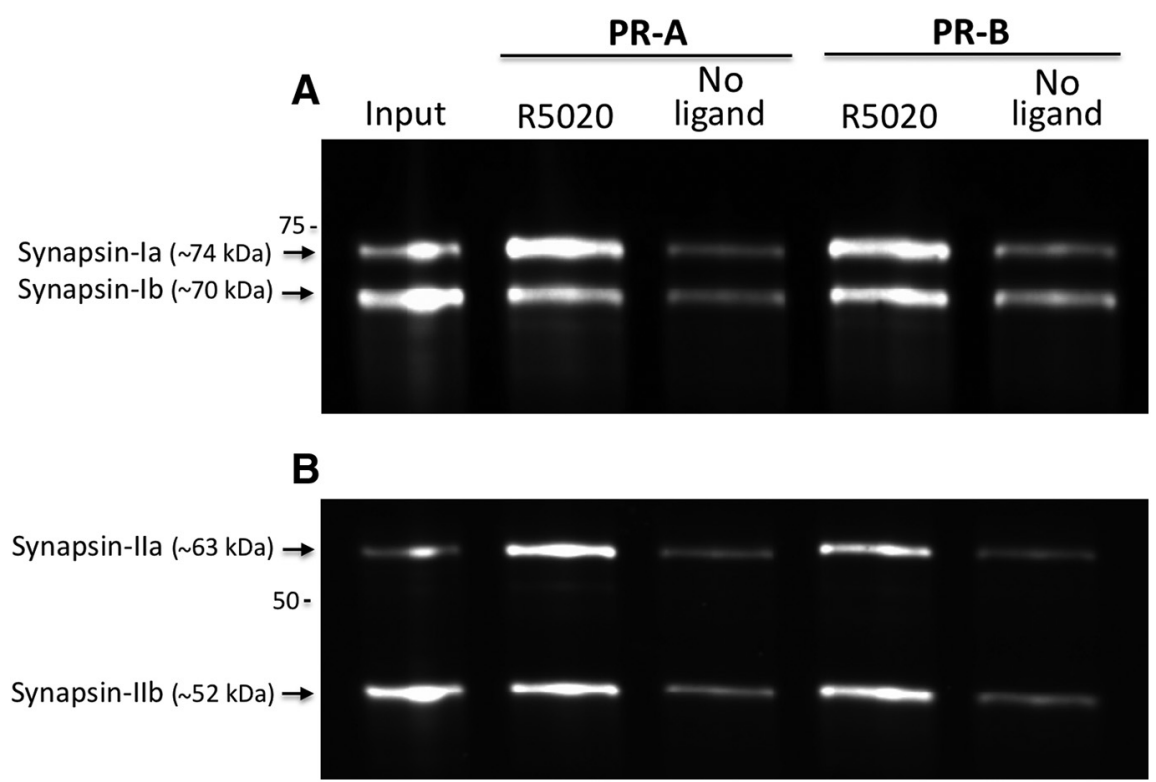

Figure 1. Hypothalamic synapsins interact with mouse PR-A and PR-B in a ligand-dependent manner. Confirmation by Western blot of MS findings that synapsin-la and synapsin-Ib $(\boldsymbol{A})$ and synapsin-Ila and synapsin-Ilb $(\boldsymbol{B})$ associate with PR-A and PR-B in the presence, of the PR agonist R5020. Input (0.25\% of total) from hypothalamic extracts (lane 1$)$.

Similar to the MS results above, additional proteins that selectively associated with unliganded PR compared with their liganded counterparts were identified by RPPA (Table 3-1).

\section{Ingenuity pathway analysis of PR interactome}

Network pathways of proteins that associate with PR, as identified by MS and RPPA, were created using Ingenuity Pathway Analysis, a program that generates protein networks using known protein interactions (Fig. 4). The highest scoring network pathway depicted shows proteins known to associate with PR (e.g., NCOA1 and NCOA2) and novel interactions of proteins from brain (e.g., synapsins and tubulin complexes) with PR identified in the present study (Fig. 4).

The use of the two proteomics approaches, MS and RPPA, enabled a more comprehensive identification of novel and known proteins that interacted with PR-A and PR-B in a ligand-dependent manner. Although MS analysis of PR-protein pull-down assays is an unbiased approach, it is less sensitive than RPPA for detection of lower-abundance proteins such as SRC-1 and SRC-2. RPPA, on the other hand, is an antibody-based targeted proteomic approach and is limited to the target antigens for which antibodies are available. For example, our RPPA platform does not have validated antibodies to synaptic

Table 3. Mouse PR-A and PR-B interact with hypothalamic proteins, identified by RPPA, in a ligand-dependent manner, with a ratio of $\mathrm{R} 5020 / \mathrm{no}$ ligand $\geq 2$ and $p<0.05$.

\begin{tabular}{|c|c|c|c|c|}
\hline Transcription & UniProt symbol & UniProt ID & $\begin{array}{l}\text { PR-A (R5020/no } \\
\text { ligand) }\end{array}$ & $\begin{array}{l}\text { PR-B (R5020/no } \\
\text { ligand) }\end{array}$ \\
\hline Steroid-receptor coactivator-1 & NCOA1 & P70365 & + & + \\
\hline Steroid receptor coactivator-2 & NCOA2 & Q61026 & + & + \\
\hline Thyroid hormone receptor-associated protein complex & MED12 & A2AGH6 & + & \\
\hline c-Fos ${ }^{\mathrm{p}}$ & FOS & P01101 & + & \\
\hline C-Jun ${ }^{p}$ & JUN & P05627 & + & \\
\hline Kruppel-like factor 4 & KLF4 & Q60793 & + & \\
\hline Autophagy-related protein 3 & ATG3 & Q9CPX6 & + & \\
\hline Autophagy related protein 12 & ATG12 & Q9CQY1 & + & \\
\hline BCL2 antagonist/killer 1 & BAK & 008734 & + & + \\
\hline Forkhead box $\mathrm{O} 1$ (metabolism) & FOXO1 & Q9R1E0 & + & + \\
\hline \multicolumn{5}{|l|}{ Signal transduction } \\
\hline Src kinase ${ }^{p}$ & $\mathrm{SRC}$ & P05480 & + & \\
\hline Signal transducer and activator of transcription $2^{\mathrm{p}}$ & STAT2 & Q9WVL2 & + & \\
\hline Epidermal growth factor receptor & EGFR & Q01279 & + & \\
\hline p70S6 kinase p $^{p}$ & KS6B & Q8BSK8 & + & \\
\hline Integrin- $\alpha 5$ & ITA5 & P11688 & + & \\
\hline Cyclin C & CCNC & Q62447 & + & \\
\hline
\end{tabular}

PProteins identified with phospho-specific antibodies. Table 3-1 shows proteins identified by RPPA that associate with PR in the absence of ligand. 

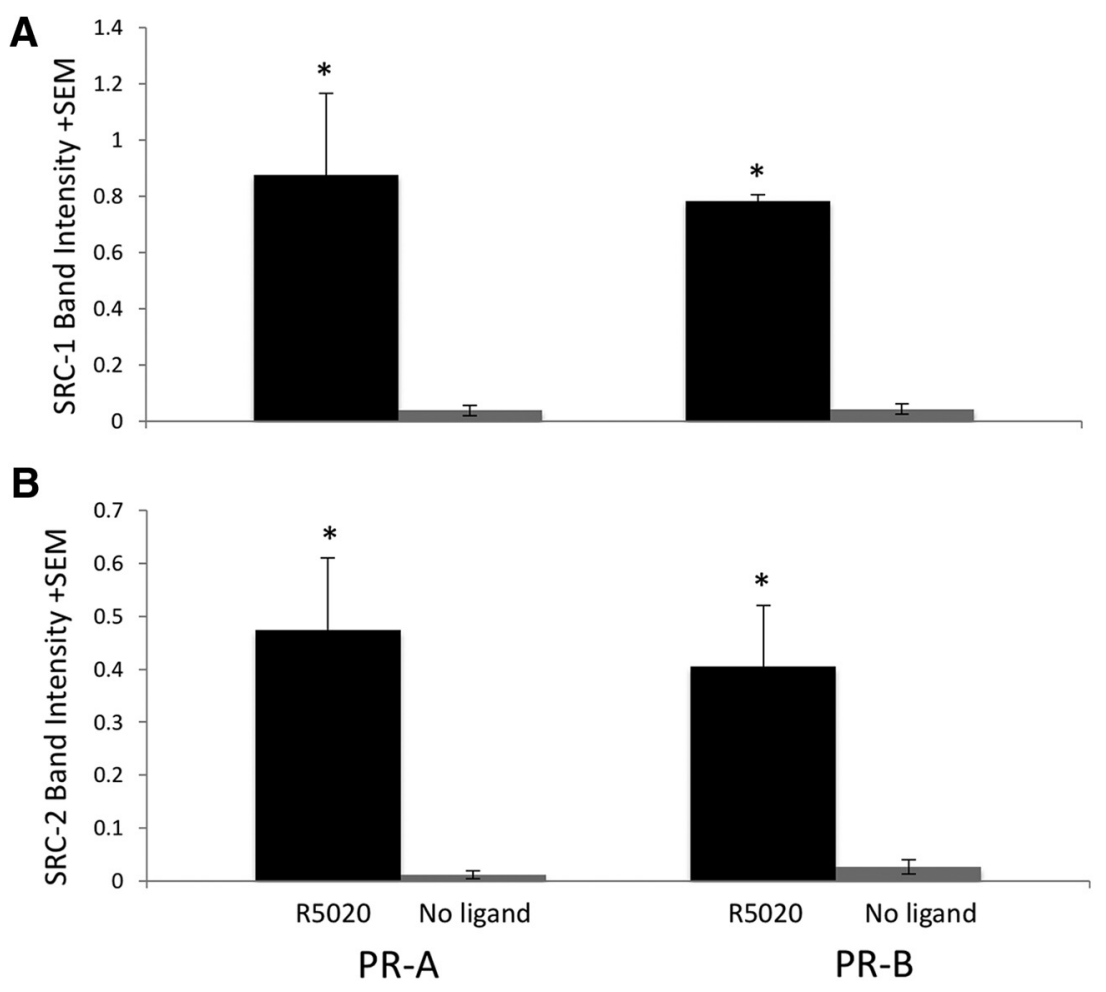

Figure 2. SRC-1 and SRC-2 from hypothalamus interact with $P R$ in a ligand-dependent manner. Western blot results show that SRC-1 (A) and SRC-2 (B) from mouse hypothalamus associate with PR-A and PR-B in the presence of the agonist R5020, but not in the absence of ligand. $* p<0.05$ indicates difference between the presence and absence of the ligand.

proteins, the largest functional groups identified by MS. Therefore, MS and RPPA served as complementary approaches for identification of PR-interacting proteins.

\section{Effects of progesterone and estradiol on synapsin-I- and PSD95-containing synapses}

To understand whether P4 could alter synapsin-I levels, primary rat cortical neurons with a mature morphology (DIV 23-25) were treated with 1 nм P4, 1 nм E2, or 1 nм P4 and E2 for $24 \mathrm{~h}$. Subsequently, cells were fixed and immunostained for synapsin-I, postsynaptic density protein 95 (PSD95), and MAP2 (marker of neuronal morphology). Quantitative analysis of immunofluorescence revealed that after exposure to $\mathrm{P} 4$, there was an increase in the linear density of synapsin-I puncta (Fig. $5 A, B$ ). E2, on the other hand, did not alter synapsin-I linear density from control (vehicle) levels; the combined treatment of P4 and E2 also had no effect on synapsin-I levels (synapsin-I puncta linear density per $10 \mu \mathrm{m}$ : control, $13.0 \pm 0.71$; P4, $16.6 \pm 0.53$; E2, $14.2 \pm 0.49$; P4 + E2, $11.6 \pm 0.58$; Fig. $5 A, B)$. When we examined levels of the postsynaptic protein PSD95, no change in linear density was observed in cells treated with P4. However, an increase in the PSD95 linear density was observed in cells treated with E2 or P4 plus E2 (PSD95 puncta linear density per $10 \mu \mathrm{m}$ : control, $10.7 \pm 0.85$; P4, $13.1 \pm 0.69$; E2, $16.6 \pm 0.68$; P4 + E2, $16.4 \pm 0.74$; Fig. $5 A, C$ ). We next sought to determine whether the changes in synaptic protein linear density induced by P4, E2, or P4 plus E2 treatments reflected an overall change in synapse number; synapses were defined as synapsin-I puncta overlapping with PSD95. In line with the observed increases in synapsin-I and PSD95 linear density in P4- and E2-treated cells, respectively, an increase in synapse number was also observed, whereas the combined treatment of P4 and E2 did not alter synapse number from control levels (synaptic puncta

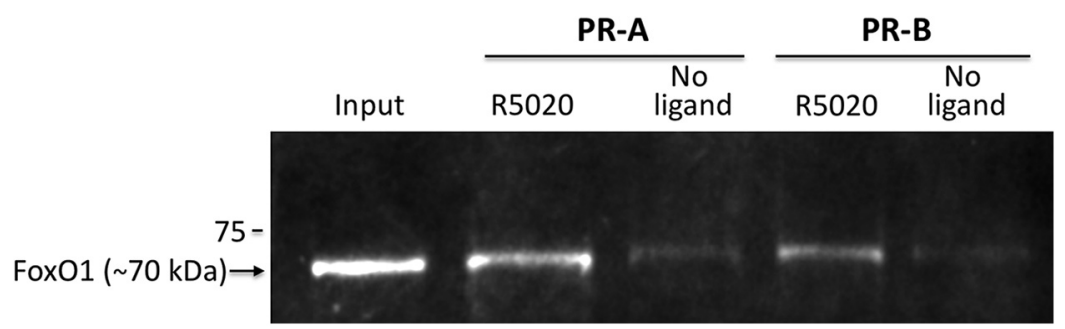

Figure 3. Hypothalamic FoxO1 interacts with mouse PR-A and PR-B when bound to the agonist, R5020. Confirmation of RPPA findings by Western blot that FoxO1 from mouse hypothalamus associates with PR-A and PR-B in the presence, but not the absence, of the PR agonist R5020. Inputs (1\% of total) of FoxO1 from hypothalamic extracts (lane 1). 


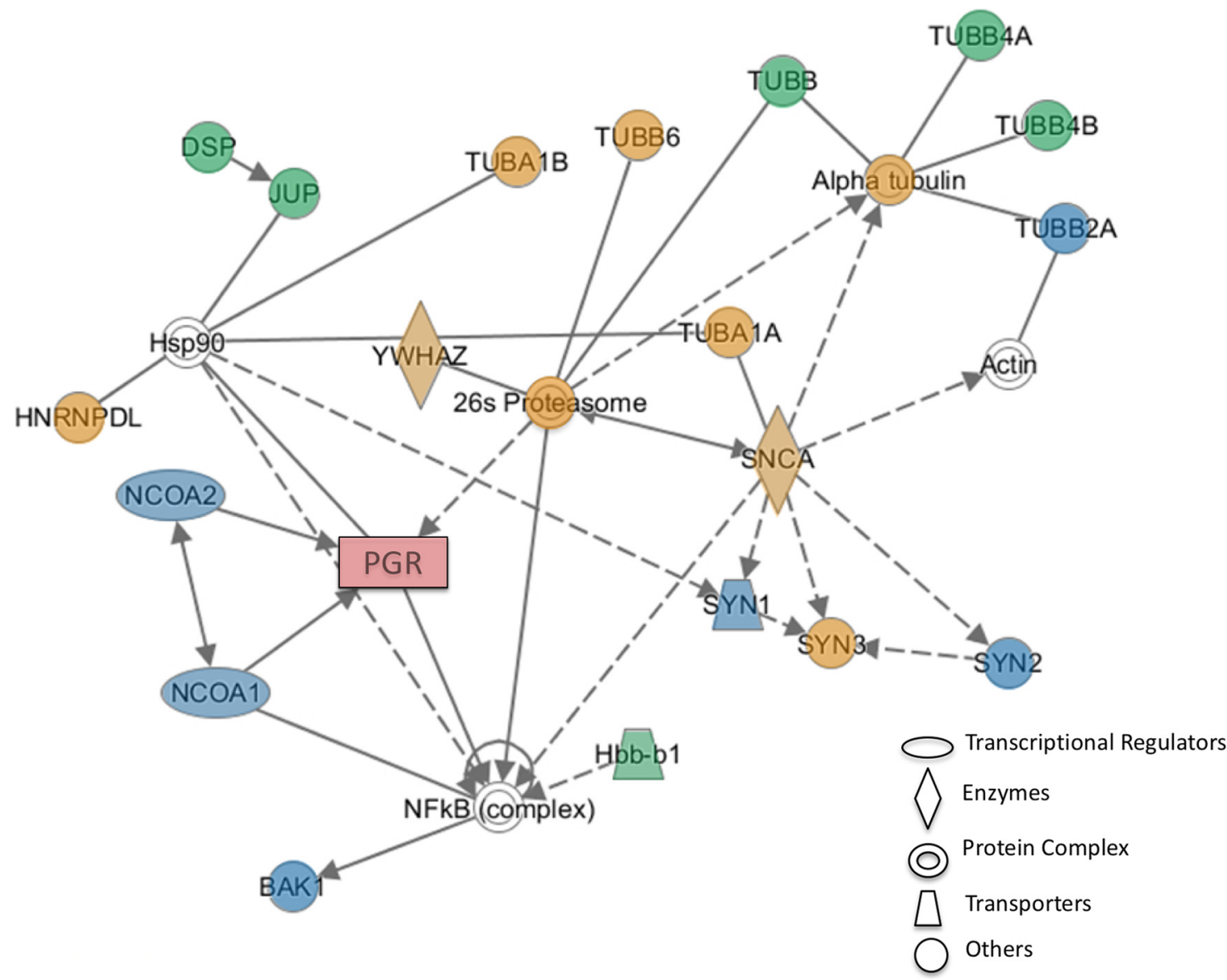

Figure 4. Network generated by Ingenuity Pathway Analysis (IPA) showing proteins from hypothalamus that associate with liganded PR-A and PR-B. Shaded proteins were identified to associate with both PR-A and PR-B (blue), PR-A only (green), or PR-B only (orange) in the present study. Unshaded proteins (white) were added to the network based on curated relationships in the IPA database. BAK1, BCL2 antagonist/killer 1; DSP, desmoplakin; JUP, junction plakoglobin; Hbbb1, hemoglobin subunit $\beta$-1; HNRNPDL, heterogeneous nuclear ribonucleoprotein D-like; NCOA1/SRC-1, steroid receptor coactivator-1; NCOA2/SRC-2, steroid receptor coactivator-2; PGR, progesterone receptor; SNCA, $\alpha$-synuclein; SYN, synapsin; TUB, tubulin; YWHAZ, 14-3-3 protein $\zeta / \delta$.

linear density per $10 \mu \mathrm{m}$ : control, $9.9 \pm 0.80 ; \mathrm{P} 4,14.3 \pm 0.49$; E2, $14.2 \pm 0.51 ;$ P4 + E2, $12.15 \pm 0.59$; Fig. $5 A, D$ ).

\section{Discussion}

Using the proteomics-based approaches of MS and RPPA, we have identified proteins from female mouse hypothalamus that form complexes with PR-A, PR-B, or both in a ligand-dependent manner. Of the proteins that associated with agonist-bound PR, synaptic modulators made up the largest group, providing evidence for novel roles of PR in synaptic plasticity. Furthermore, in primary cortical neuronal cultures, we provide evidence that progesterone increases synapses containing synapsin-I protein, which selectively associated with ligand-bound PR. The other major protein groups from hypothalamus that interacted with the PR isoforms are kinases and signaling proteins, transcriptional and translational regulators, and proteins linked to energy metabolism.

\section{PR and synaptic modulation}

Progestins modulate dendritic spine density and synapse numbers in the female rat hippocampus, ventromedial hypothalamus (VMH), and prefrontal cortex, and in cultured rat cortical neurons (Woolley and McEwen, 1993; McEwen and Woolley, 1994; Chen et al., 2009; Griffin et al., 2010; Chisholm and Juraska, 2012; Sanchez et al., 2013). Most prior studies have examined the combined effects of E2 and P4 on dendritic spines, revealing that E2 increases, whereas E2 plus P4 decreases, dendritic spines in the hippocampus (McEwen and Woolley, 1994; Murphy and Segal, 2000), prefrontal cortex (Chisholm and Juraska, 2012), and hypothalamus (Griffin et al., 2010). Previously, it has been shown that P4 treatment for 2 wks increases dendritic spine density in cortical pyramidal neurons of ovariectomized rats (Chen et al., 2009). The present findings extended those of Chen et al. (2009) to reveal that treatment with $\mathrm{P} 4$ for $24 \mathrm{~h}$ increases synapses in cortical neurons, as indicated by immunohistochemical localization of synapsin-I and PSD95 in the newly formed synapses. In further support of progestin-dependent synapse modulation, estradiol-induced PR have been detected in neuronal processes in the hypothalamus (Blaustein et al., 1988) and dendritic spines and axon terminals in the hippocampus (Waters et al., 2008; Mitterling et al., 2010) of female rodents. 
A
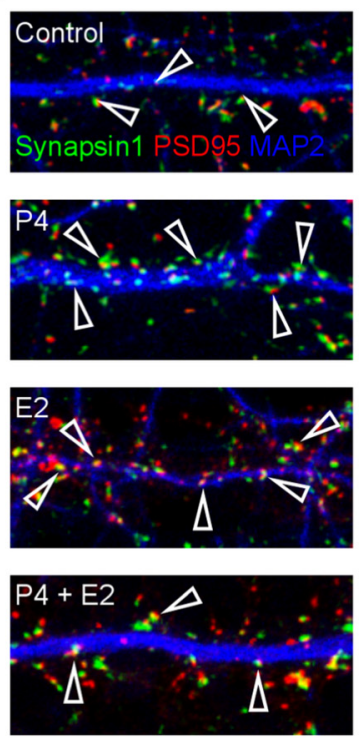
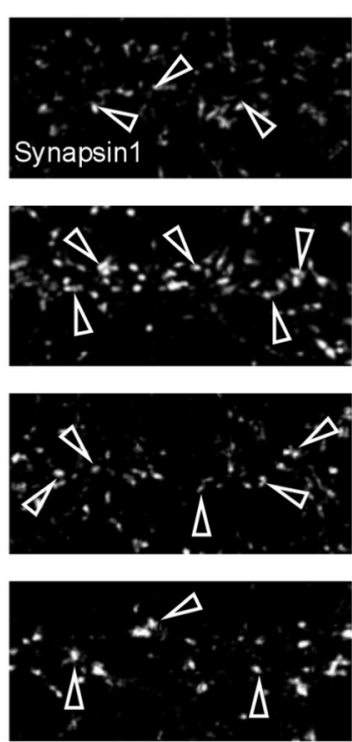
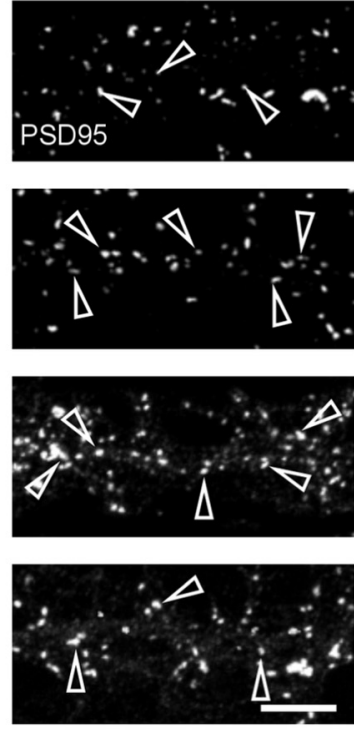

B

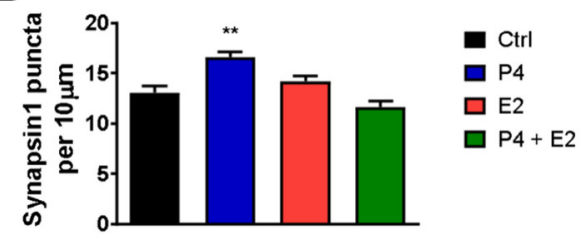

C

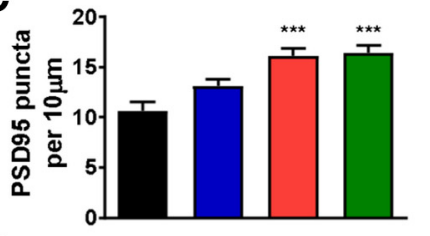

D

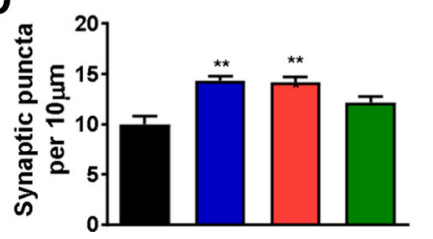

- Ctrl

口4

$\square$ E2

$\square$ P4 + E2

- Ctrl

D4

$\square \mathrm{E} 2$

$\square \mathrm{P} 4+\mathrm{E} 2$

Figure 5. Progesterone (P4) and estradiol (E2) alter synapse number and synaptic protein expression. $\boldsymbol{A}$, Representative confocal images of primary rat cortical neurons treated with 1 nм P4, 1 nм E2, or both for $24 \mathrm{~h}$. Images are for synapsin-I (green) and PSD95 (red) along MAP2-positive dendrites (blue). Open arrowheads indicate colocalized synapsin-I and PSD95 puncta and thus, synapses. $\boldsymbol{B}$, Quantitative analysis of synapsin-I linear density; treatment with P4 increased synapsin-I density compared with control (vehicle) condition. C, PSD95 linear density was increased over control levels after treatment with E2 alone or combined P4 and E2 treatment. $\boldsymbol{D}$, Measurement of synaptic puncta, defined as synapsin-I puncta positive for PSD95, was increased after treatment with either P4 or E2. $* * p<0.01 ; * * * p<0.001$; scale bar $=5 \mu \mathrm{m}$.

The present findings, that synaptic proteins from mouse brain interact with PR, provide insight into novel mechanisms for progestin effects on synaptic functions. As identified by MS and Western blot, synapsin-I and synapsin-II interacted with both PR isoforms in a ligand-dependent manner. In addition, P4 increased synaptic density in rat primary cortical neurons, indicated by an increase in synapsin-I-positive puncta, suggesting that synapsin-I function in P4-mediated synapse addition is conserved among species. The present findings confirm the synaptogenic role of progestins and suggest a function for synapsin-I in progestin-mediated synapse formation. Synapsins may influence cortical synapses through direct association with PR or, alternatively, may function with PR indirectly or through PR-independent pathways.

Synapsins, including synapsin-I and synapsin-II, are presynaptic phosphoproteins that are integral in axon formation, synaptic maturation, transmission, and remodeling in excitatory synapses (Chin et al., 1995; Ferreira et al., 1998; Bogen et al., 2009; Cesca et al., 2010). Synapsins contain binding sites for MAPK/Erk and src kinase (Jovanovic et al., 1996; Foster-Barber and Bishop, 1998), kinases identified in the present study to interact with ligand-bound PR. Taken together, these findings suggest that PR increase synapses through regulating expression, transport, or phosphorylation of synapsins. Given the rapid effects of estrogens on synapses via kinases and synaptic proteins (Srivastava et al., 2008; Sellers et al., 2015), it will be important to explore the function of kinases identified here on progestin-mediated synapse formation.
Multiple synaptic proteins interacted with $\mathrm{PR}$ in an isoform-specific manner. For example, synaptogyrin-III, which is upregulated in the hypothalamus by estradiol (Malyala et al., 2005), interacted only with PR-A, suggesting a role for this protein in hormone-dependent synaptic changes. Synapsin-III, which is expressed in cell bodies of neuronal progenitors and has been implicated in neurogenesis (Kao et al., 2008), interacted only with PR-B, indicating a role for PR-B in neurogenesis (Barha et al., 2011; Bali et al., 2012). Interestingly, tubulins, which are components of microtubules that provide structural framework for synaptic junctions, postsynaptic densities, and synaptic vesicles (Kelly and Cotman, 1978; Zisapel et al., 1980), formed complexes with PR in an isoformspecific and ligand-dependent manner, another novel finding of the current study. Tubulin $\beta-2 A$ and tubulin $\beta-4 B$, which are upregulated by estradiol in female hippocampus, were associated with liganded PR in the present study (Pechenino and Frick, 2009; Sárvári et al., 2015). Taken together, these findings suggest an important role for tubulins in progestin-mediated synaptic plasticity in the brain.

\section{PR and signal transduction}

PR, acting through kinase activation, exert rapid effects in the brain (Mani et al., 2006; Tetel, 2009; Sanchez et al., 2013). In further support of rapid effects of $P R$ in the brain, we found that MAPK1 associated with liganded PR-B, but not PR-A. Consistent with these findings, MAPK1 associates with and phosphorylates PR-B, but not PR-A, in P4-treated breast cancer cells (Clemm et al., 2000; 
Boonyaratanakornkit et al., 2007). In addition, we detected hormone-dependent interactions between src kinase and EGFR with PR-A, but not PR-B. These differential interactions of signaling molecules with $\mathrm{PR}$ may be important for isoform-specific rapid effects of PR in brain.

\section{PR and energy metabolism}

Although the profound effects of estradiol on decreasing feeding and weight gain and increasing activity in women and female rodents is well known (Blaustein and Wade, 1976; Clegg, 2012; Bless et al., 2014, 2016), the effects of progesterone on metabolism are less studied. However, progesterone attenuates the effects of estrogens on food intake and carbohydrate metabolism in female primates and women, respectively (Kemnitz et al., 1989; D'Eon et al., 2002; Michopoulos and Wilson, 2011). The present findings reveal that creatine kinase $B$ and phytanoyl COA-hydroxylase interacting protein-like, both involved in energy metabolism (James et al., 2012; Schlattner et al., 2016), associated with PR-A, but not PR-B, implicating a function for hypothalamic PR-A in energy homeostasis.

In further support of PR function in energy homeostasis, the transcriptional regulator FoxO1 interacted with both $\mathrm{PR}$ isoforms. FoxO1 is expressed in energy regulation centers, including the $\mathrm{VMH}$ and arcuate nucleus (Kim et al., 2006; Fukuda et al., 2008), and enhances food intake by increasing neuropeptide $Y$ and agouti-related protein mRNA expression (Kitamura et al., 2006; Huang et al., 2012). In addition, FoxO1 attenuates leptin signaling and is regulated by leptin (Yang et al., 2009; Ren et al., 2013). Taken together with the studies above, the present findings suggest that hypothalamic PR function in energy homeostasis and indicate the need for further study of progestins in food intake and energy metabolism.

\section{PR and transcriptional regulation}

PR-A and PR-B act as transcription factors in concert with other transcriptional regulators, including nuclear receptor coactivators and RNA polymerases (O'Malley et al., 2012; Tetel and Acharya, 2013; Dasgupta et al., 2014). The present findings reveal that SRC-1 and SRC-2 from hypothalamus interact with agonist-bound PR-A and PR-B, consistent with our earlier work that these coactivators are coexpressed with the PR isoforms in the female mouse hypothalamus (Acharya et al., 2015) and function in the brain to modulate PR-dependent behaviors (MolendaFigueira et al., 2006).

Although the role of the transcription factor FoxO1 in energy metabolism is discussed above, it has also been linked to stress and depression. FoxO1 expression is upregulated by glucocorticoids (Qin et al., 2014) and is downregulated by antidepressants (Polter et al., 2009). Thus, exploring a potential role of FoxO1 and PR interaction may provide more insight into the role of progesterone in stress disorders.

PR-A, but not PR-B, interacted with MED12, which bridges transcription factors with RNA polymerases and is integral for vertebrate neuronal development (Wang et al., 2006; Rocha et al., 2010; Kim et al., 2016). In humans,
MED12 mutations lead to $\mathrm{X}$-linked mental retardation (Philibert et al., 2001; Risheg et al., 2007; Schwartz et al., 2007). Taken together, the present findings provide a mechanism by which progestins mediate brain development (Quadros et al., 2008; López and Wagner, 2009) through PRA-MED12 interactions. In future studies, it will be important to explore whether mutations in MED12 disrupt interactions with PR and alter brain development.

Based on previous studies and the current findings, a majority of tubulins and synaptic proteins, including synapsin isoforms and $\alpha$-synuclein, likely associate with PR through a 26S proteasome complex as shown by Ingenuity Pathway Analysis (Fig. 4). Interestingly, 26S protease subunit associated with PR-B, but not PR-A, in the current study, suggesting differential downregulation of the PR isoforms after P4 treatment (Lange et al., 2000). Ingenuity Pathway Analysis incorporates previously identified proteins that are known to associate with PR, in either the liganded or unliganded state, with the present findings. For example, proteins known from previous studies to interact with $\mathrm{PR}$, including a molecular chaperone hsp90 (DeMarzo et al., 1991; Johnson et al., 1994; Tetel et al., 1997), actin (known for its role in PR- mediated growth cone formation and modulation of dendritic spines; Sanchez et al., 2013; Wessel et al., 2014), and nuclear factor- $\kappa \mathrm{B}$ (a stress-response regulator; Cutolo et al., 2004), were added to the network (Fig. 5) by Ingenuity Pathway Analysis. However, given that the present study focused on hypothalamic proteins that interact with PR in a ligand-dependent manner, only these proteins from the current findings were added to the network (shaded proteins in Fig. 5). In summary, this network confirms previously known interactions of PR with nuclear receptor coactivators (e.g., SRC-1/NCOA1 and SRC-2/NCOA2) and provides evidence for novel mechanisms by which progestins modulate synapses, revealing multiple regulatory levels of PR action in the brain.

Although genome-wide analysis of PR binding sites in mouse uterus (Rubel et al., 2012) and computational models have been used to predict the human PR interactome (Liu et al., 2015), to the best of our knowledge, the PR interactome has not been previously analyzed. Despite different approaches used in the previous studies (Rubel et al., 2012; Liu et al., 2015), the present findings of association of PR with transcriptional regulators, multiple tubulin isoforms, Src kinase, and EGFR were consistent with these published reports. Other studies have focused on receptor-dependent transcriptome or proteome of steroid receptors, including PR and estrogen receptors (Tan et al., 2012; Yang et al., 2017). Finally, proximity mapping has been used in cultured cells to identify proteins showing ligand-dependent interactions with receptors for glucocorticoids and androgens (Lempiäinen et al., 2017). Although these studies have found some interacting partners similar to those of the present study, including SRC-1, SRC-2, and MED12, none of these experiments investigated interacting proteins from the brain, and more specifically the hypothalamus. Therefore, the current study has identified a number of novel proteins interacting 
with PR, including synaptic proteins and regulators of metabolism.

A comprehensive and novel approach of combining MS and RPPA enabled us to identify a diverse and new group of protein complexes in the brain that interact with PR in a ligand- and isoform-specific manner. Although MS is an unbiased approach for identification of novel proteins, it requires large amounts of protein input, which could result in difficulty identifying lowabundance proteins. RPPA complemented the MS and expanded the coverage for low-abundance proteins. Both approaches identified many proteins in three major groups, including those with roles in transcription, metabolism, and signal transduction. In future studies, it will be important to investigate interactions between endogenous hypothalamic PR with proteins using different approaches (e.g., coimmunoprecipitation assays) to confirm and extend the current findings.

Through the identification of multiple components of PR complexes in the brain, the current study provides insights into various mechanisms of PR in physiology and disease. In addition, identification of protein complexes from female mouse hypothalamus that interact differentially with PR-A and PR-B sheds light on mechanisms that may contribute to PR isoform-specific functions. This study provides a novel role for synapsin-I in progestininduced increase in synapses. These findings offer further evidence for overlapping pathways in genomic and nongenomic regulation in synaptic physiology and energy metabolism. In future studies, it will be important to apply the present strategies to identify factors involved in ligand-independent activation of PR (Denner et al., 1990; Mani et al., 1994; Tetel and Lange, 2009) that will provide important insights into PR action in physiology, behavior, and disease.

\section{References}

Acharya KD, Finkelstein SD, Bless EP, Nettles SA, Mulac-Jericevic B, Conneely OM, Mani SK, Tetel MJ (2015) Estradiol preferentially induces progestin receptor-A (PR-A) over PR-B in cells expressing nuclear receptor coactivators in the female mouse hypothalamus. eNeuro 2:0012-0015. CrossRef

Apostolakis EM, Ramamurphy M, Zhou D, Oñate S, O'Malley BW (2002) Acute disruption of select steroid receptor coactivators prevents reproductive behavior in rats and unmasks genetic adaptation in knockout mice. Mol Endocrinol 16:1511-1523. CrossRef

Bagchi MK, Tsai SY, Tsai MJ, O’Malley BW (1991) Progesterone enhances target gene transcription by receptor free of heat shock proteins hsp90, hsp56, and hsp70. Mol Cell Biol 11:4998-5004. Medline

Bali N, Arimoto JM, Iwata N, Lin SW, Zhao L, Brinton RD, Morgan TE, Finch CE (2012) Differential responses of progesterone receptor membrane component-1 (Pgrmc1) and the classical progesterone receptor (Pgr) to $17 \beta$-Estradiol and progesterone in hippocampal subregions that support synaptic remodeling and neurogenesis. Endocrinology 153:759-769. CrossRef Medline

Barha CK, Ishrat T, Epp JR, Galea LAM, Stein DG (2011) Progesterone treatment normalizes the levels of cell proliferation and cell death in the dentate gyrus of the hippocampus after traumatic brain injury. Exp Neurol 231:72-81. CrossRef

Beyer C, Damm N, Brito V, Küppers E (2002) Developmental expression of progesterone receptor isoforms in the mouse midbrain. Neuroreport 13:877-880. Medline
Blaustein JD (2008) Progesterone and progestin receptors in the brain: the neglected ones. Endocrinology 149:2737-2738. CrossRef Medline

Blaustein JD, Wade GN (1976) Ovarian influences on the meal patterns of female rats. Physiol Behav 17:201-208. Medline

Blaustein JD, Ismail N (2013) Enduring influence of pubertal stressors on behavioral response to hormones in female mice. Horm Behav 64:390-398. CrossRef Medline

Blaustein JD, King JC, Toft DO, Turcotte J (1988) Immunocytochemical localization of estrogen-induced progestin receptors in guinea pig brain. Brain Res 474:1-15. CrossRef

Bless EP, Reddy T, Acharya KD, Beltz BS, Tetel MJ (2014) Oestradiol and diet modulate energy homeostasis and hypothalamic neurogenesis in the adult female mouse. J Neuroendocrinol 26:805-816. CrossRef Medline

Bless EP, Yang J, Acharya KD, Nettles SA, Vassoler FM, Byrnes EM, Tetel MJ (2016) Adult neurogenesis in the female mouse hypothalamus: estradiol and high-fat diet alter the generation of newborn neurons expressing estrogen receptor alpha. eNeuro 3:1-11. CrossRef

Bogen IL, Jensen V, Hvalby O, Walaas SI (2009) Synapsindependent development of glutamatergic synaptic vesicles and presynaptic plasticity in postnatal mouse brain. Neuroscience 158: 231-241. CrossRef Medline

Boonyaratanakornkit V, McGowan E, Sherman L, Mancini MA, Cheskis BJ, Edwards DP (2007) The role of extranuclear signaling actions of progesterone receptor in mediating progesterone regulation of gene expression and the cell cycle. Mol Endocrinol 21:359-375. CrossRef Medline

Brinton RD, Thompson RF, Foy MR, Baudry M, Wang J, Finch CE, Morgan TE, Pike CJ, Mack WJ, Stanczyk FZ, Nilsen J (2008) Progesterone receptors: form and function in brain. Front Neuroendocrinol 29:313-339. CrossRef Medline

Carbajo P, Christensen K, Edwards DP, Skafar DF (1996) Binding of $[3 \mathrm{H}]$ progesterone to the human progesterone receptor: differences between individual and mixed isoforms. Endocrinology 137:23392346. CrossRef

Cesca F, Baldelli P, Valtorta F, Benfenati F (2010) The synapsins: key actors of synapse function and plasticity. Prog Neurobiol 91:313348. CrossRef Medline

Chang $\mathrm{CH}$, Zhang M, Rajapakshe K, Coarfa C, Edwards D, Huang S, Rosen JM (2015) Mammary stem cells and tumor-initiating cells are more resistant to apoptosis and exhibit increased DNA repair activity in response to DNA damage. Stem Cell Reports 5:378391. CrossRef Medline

Chen JR, Yan YT, Wang TJ, Chen LJ, Wang YJ, Tseng GF (2009) Gonadal hormones modulate the dendritic spine densities of primary cortical pyramidal neurons in adult female rat. Cereb Cortex 19:2719-2727. CrossRef

Cheng KW, Cheng CK, Leung PC (2001) Differential role of PR-A and $-B$ isoforms in transcription regulation of human $\mathrm{GnRH}$ receptor gene. Mol Endocrinol 15:2078-2092. CrossRef Medline

Chin LS, Li L, Ferreira A, Kosik KS, Greengard P (1995) Impairment of axonal development and of synaptogenesis in hippocampal neurons of synapsin I-deficient mice. Proc Natl Acad Sci U S A 92:9230-9234. Medline

Chisholm NC, Juraska JM (2012) Effects of long-term treatment with estrogen and medroxyprogesterone acetate on synapse number in the medial prefrontal cortex of aged female rats. Menopause 19:804-811. CrossRef

Clegg DJ (2012) Minireview: the year in review of estrogen regulation of metabolism. Mol Endocrinol 26:1957-1960. CrossRef Medline

Clemm DL, Sherman L, Boonyaratanakornkit V, Schrader WT, Weigel NL, Edwards DP (2000) Differential hormone-dependent phosphorylation of progesterone receptor $A$ and $B$ forms revealed by a phosphoserine site-specific monoclonal antibody. Mol Endocrinol 14:52-65. CrossRef

Conneely OM, Lydon JP, De Mayo F, O'Malley BW (2000) Reproductive functions of the progesterone receptor. J Soc Gynecol Investig 7:S25-S32. Medline 
Cutolo M, Sulli A, Capellino S, Villaggio B, Montagna P, Seriolo B, Straub R (2004) Sex hormones influence on the immune system: basic and clinical aspects in autoimmunity. Lupus 13:635-638. CrossRef Medline

D'Eon T, Sharoff C, Chipkin SR, Grow D, Ruby BC, Braun B (2002) Regulation of exercise carbohydrate metabolism by estrogen and progesterone in women. Am J Physiol Endocrinol Metab 283: E1046-E1105.

Dasgupta S, Lonard DM, O'Malley BW (2014) Nuclear receptor coactivators: master regulators of human health and disease. Annu Rev Med 65:279-292. CrossRef Medline

DeMarzo AM, Beck CA, Onate SA, Edwards DP (1991) Dimerization of mammalian progesterone receptors occurs in the absence of DNA and is related to the release of the $90-\mathrm{kDa}$ heat shock protein. Proc Natl Acad Sci U S A 88:72-76.

Denner LA, Weigel NL, Maxwell BL, Schrader WT, O'Malley BW (1990) Regulation of progesterone receptor-mediated transcription by phosphorylation. Science 250:1740-1743. Medline

Diep CH, Daniel AR, Mauro LJ, Knutson TP, Lange CA (2015) Progesterone action in breast, uterine, and ovarian cancers. J Mol Endocrinol 54:R31-R53. CrossRef Medline

Ferreira A, Chin LS, Li L, Lanier LM, Kosik KS, Greengard P (1998) Distinct roles of synapsin I and synapsin II during neuronal development. Mol Med 4:22-28. Medline

Foster-Barber A, Bishop JM (1998) Src interacts with dynamin and synapsin in neuronal cells. Proc Natl Acad Sci U S A 95:46734677. Medline

Fukuda M, Jones JE, Olson D, Hill J, Lee CE, Gautron L, Choi M, Zigman JM, Lowell BB, Elmquist JK (2008) Monitoring FoxO1 localization in chemically identified neurons. J Neurosci 28:1364013648. CrossRef Medline

Giangrande PH, Pollio G, McDonnell DP (1997) Mapping and characterization of the functional domains responsible for the differential activity of the $A$ and $B$ isoforms of the human progesterone receptor. J Biol Chem 272:32889-32900. CrossRef

Glynn MW, McAllister AK (2006) Immunocytochemistry and quantification of protein colocalization in cultured neurons. Nat Protoc 1:1287-1296. CrossRef Medline

González-Flores O, Shu J, Camacho-Arroyo I, Etgen AM (2004) Regulation of lordosis by cyclic 3',5'-guanosine monophosphate, progesterone, and its 5alpha-reduced metabolites involves mitogen-activated protein kinase. Endocrinology 145:5560-5567. CrossRef Medline

Goswami D, Callaway C, Pascal BD, Kumar R, Edwards DP, Griffin PR (2014) Influence of domain interactions on conformational mobility of the progesterone receptor detected by hydrogen/deuterium exchange mass spectrometry. Structure 22:961-973. CrossRef Medline

Griffin GD, Ferri-Kolwicz SL, Reyes BA, Van Bockstaele EJ, Flanagan-Cato LM (2010) Ovarian hormone-induced reorganization of oxytocin-labeled dendrites and synapses lateral to the hypothalamic ventromedial nucleus in female rats. J Comp Neur 518:4531-4545. CrossRef Medline

Han X, He L, Xin L, Shan B, Ma B (2011) PeaksPTM: mass spectrometry-based identification of peptides with unspecified modifications. J Proteome Res 10:2930-2936. CrossRef Medline

Han Y, Ma B, Zhang K (2004) SPIDER: software for protein identification from sequence tags with de novo sequencing error. Proc IEEE Comput Syst Bioinform Conf 206-215.

Hill KK, Roemer SC, Churchill ME, Edwards DP (2012) Structural and functional analysis of domains of the progesterone receptor. Mol Cell Endocrinol 348:418-429. CrossRef Medline

Horwitz KB, Sheridan PL, Wei LL, Krett NL (1990) Human progesterone receptors: synthesis, structure, and phosphorylation. Prog Clin Biol Res 322:41-52. Medline

Hovland AR, Powell RL, Takimoto GS, Tung L, Horwitz KB (1998) An $\mathrm{N}$-terminal inhibitory function, IF, suppresses transcription by the A-isoform but not the B-isoform of human progesterone receptors. J Biol Chem 273:5455-5460. CrossRef
Huang H, Kong D, Byun KH, Ye C, Koda S, Lee DH, Oh BC, Lee SW, Lee B, Zabolotny JM, Kim MS, Bjørbæk C, Lowell BB, Kim YB (2012) Rho-kinase regulates energy balance by targeting hypothalamic leptin receptor signaling. Nat Neurosci 15:1391-1398. CrossRef Medline

Hull EM, Franz JR, Snyder AM, Nishita JK (1980) Perinatal progesterone and learning, social and reproductive behavior in rats. Physiol Behav 24:251-256. Medline

Irwin RW, Yao J, Hamilton RT, Cadenas E, Brinton RD, Nilsen J (2008) Progesterone and estrogen regulate oxidative metabolism in brain mitochondria. Endocrinology 149:3167-3175. CrossRef Medline

James R, Searcy JL, Le Bihan T, Martin SF, Gliddon CM, Povey J, Deighton RF, Kerr LE, McCulloch J, Horsburgh K (2012) Proteomic analysis of mitochondria in APOE transgenic mice and in response to an ischemic challenge. J Cereb Blood Flow Metab 32:164-176. CrossRef

Johnson JL, Toft DO (1994) A novel chaperone complex for steroid receptors involving heat shock proteins, immunophilins, and p23. J Biol Chem 269:24989-22499. Medline

Johnson JL, Beito TG, Krco CJ, Toft DO (1994) Characterization of a novel 23-kilodalton protein of unactive progesterone receptor complexes. Mol Cell Biol 14:1956-1963. Medline

Jovanovic JN, Benfenati F, Siow YL, Sihra TS, Sanghera JS, Pelech SL, Greengard P, Czernik AJ (1996) Neurotrophins stimulate phosphorylation of synapsin I by MAP kinase and regulate synapsin I-actin interactions. Proc Natl Acad Sci U S A 93:3679-3683. Medline

Kao HT, Li P, Chao HM, Janoschka S, Pham K, Feng J, McEwen BS, Greengard P, Pieribone VA, Porton B (2008) Early involvement of synapsin III in neural progenitor cell development in the adult hippocampus. J Comp Neur 507:1860-1870. CrossRef Medline

Kastner P, Krust A, Turcotte B, Stropp U, Tora L, Gronemeyer H, Chambon P (1990) Two distinct estrogen-regulated promoters generate transcripts encoding the two functionally different human progesterone receptor forms A and B. EMBO J 9:1603-1614.

Kelly PT, Cotman CW (1978) Synaptic proteins. Characterization of tubulin and actin and identification of a distinct postsynaptic density polypeptide. J Cell Biol 79:173-183. Medline

Kemnitz JW, Gibber JR, Lindsay KA, Eisele SG (1989) Effects of ovarian hormones on eating behaviors, body weight, and glucoregulation in rhesus monkeys. Horm Behav 23:235-250. Medline

Keyes KM, Cheslack-Postava K, Westhoff C, Heim CM, Haloossim M, Walsh K, Koenen K (2013) Association of hormonal contraceptive use with reduced levels of depressive symptoms: a national study of sexually active women in the United States. Am J Epidemiol 178:1378-1388. CrossRef Medline

Kim MS, Pak YK, Jang PG, Namkoong C, Choi YS, Won JC, Kim KS, Kim SW, Kim HS, Park JY, Kim YB, Lee KU (2006) Role of hypothalamic Foxo1 in the regulation of food intake and energy homeostasis. Nat Neurosci 9:901-906. CrossRef Medline

Kim NH, Livi CB, Yew PR, Boyer TG (2016) Mediator subunit Med12 contributes to the maintenance of neural stem cell identity. BMC Dev Biol 16:17. CrossRef Medline

Kitamura T, Feng Y, Kitamura YI, Chua SC, Jr., Xu AW, Barsh GS, Rossetti L, Accili D (2006) Forkhead protein FoxO1 mediates Agrp-dependent effects of leptin on food intake. Nat Med 12:534540. CrossRef Medline

Lange CA, Shen T, Horwitz KB (2000) Phosphorylation of human progesterone receptors at serine-294 by mitogen-activated protein kinase signals their degradation by the $26 \mathrm{~S}$ proteasome. Proc Natl Acad Sci U S A 97:1032-1037. Medline

Lempiäinen JK, Niskanen EA, Vuoti KM, Lampinen RE, Göös H, Varjosalo M, Palvimo JJ (2017) Agonist-specific protein interactomes of glucocorticoid and androgen receptor as revealed by proximity mapping. Mol Cell Proteomics 16:1462-1474. CrossRef Medline

Leonhardt SA, Boonyaratanakornkit V, Edwards DP (2003) Progesterone receptor transcription and non-transcription signaling mechanisms. Steroids 68:761-770. Medline 
Liu JL, Peng Y, Fu YS (2015) Efficient prediction of progesterone receptor interactome using a support vector machine model. Int $\mathrm{J}$ Mol Sci 16:4774-4785. CrossRef Medline

López V, Wagner CK (2009) Progestin receptor is transiently expressed perinatally in neurons of the rat isocortex. J Comp Neur 512:124-139. CrossRef Medline

Ma B, Zhang K, Hendrie C, Liang C, Li M, Doherty-Kirby A, Lajoie G (2003) PEAKS: powerful software for peptide de novo sequencing by tandem mass spectrometry. Rapid Commun Mass Spectrom 17:2337-2342. CrossRef Medline

MacLean B, Tomazela DM, Shulman N, Chambers M, Finney GL, Frewen B, Kern R, Tabb DL, Liebler DC, MacCoss MJ (2010) Skyline: an open source document editor for creating and analyzing targeted proteomics experiments. Bioinformatics 26:966-968. CrossRef Medline

Malyala A, Kelly MJ, Rønnekleiv OK (2005) Estrogen modulation of hypothalamic neurons: activation of multiple signaling pathways and gene expression changes. Steroids 70:397-406. CrossRef Medline

Mani SK, Allen JMC, Clark JH, Blaustein JD, O'Malley BW (1994) Convergent pathways for steroid hormone- and neurotransmitterinduced rat sexual behavior. Science 265:1246-1249. CrossRef

Mani SK, Reyna AM, Chen JZ, Mulac-Jericevic B, Conneely OM (2006) Differential response of progesterone receptor isoforms in hormone-dependent and -independent facilitation of female sexual receptivity. Mol Endocrinol 20:1322-1332. CrossRef Medline

McEwen BS, Woolley CS (1994) Estradiol and progesterone regulate neuronal structure and synaptic connectivity in adult as well as developing brain. Exp Gerontol 29:431-436. Medline

Michopoulos V, Wilson ME (2011) Body weight decreases induced by estradiol in female rhesus monkeys are dependent upon social status. Physiol Behav 102:382-388. CrossRef Medline

Mitterling KL, Spencer JL, Dziedzic N, Shenoy S, McCarthy K, Waters EM, McEwen BS, Milner TA (2010) Cellular and subcellular localization of estrogen and progestin receptor immunoreactivities in the mouse hippocampus. J Comp Neur 518:2729-2743. CrossRef Medline

Molenda HA, Griffin AL, Auger AP, McCarthy MM, Tetel MJ (2002) Nuclear receptor coactivators modulate hormone-dependent gene expression in brain and female reproductive behavior in rats. Endocrinology 143:436-444. CrossRef

Molenda-Figueira HA, Williams CA, Griffin AL, Rutledge EM, Blaustein JD, Tetel MJ (2006) Nuclear receptor coactivators function in estrogen receptor- and progestin receptor-dependent aspects of sexual behavior in female rats. Horm Behav 50:383-392. CrossRef Medline

Molenda-Figueira HA, Murphy SD, Shea KL, Siegal NK, Zhao Y, Chadwick JG, Jr., Denner LA, Tetel MJ (2008) Steroid receptor coactivator-1 from brain physically interacts differentially with steroid receptor subtypes. Endocrinology 149:5272-5279. CrossRef

Mora S, Dussaubat N, Díaz-Véliz G (1996) Effects of the estrous cycle and ovarian hormones on behavioral indices of anxiety in female rats. Psychoneuroendocrinology 21:609-620. Medline

Mulac-Jericevic B, Lydon JP, DeMayo FJ, Conneely OM (2003) Defective mammary gland morphogenesis in mice lacking the progesterone receptor B isoform. Proc Natl Acad Sci U S A 100:9744-9749. CrossRef Medline

Murphy DD, Segal M (2000) Progesterone prevents estradiolinduced dendritic spine formation in cultured hippocampal neurons. Neuroendocrinology 72:133-143. Medline Medline

O'Malley BW, Malovannaya A, Qin J (2012) Nuclear receptor and coregulator proteomics-2012 and beyond. Mol Endocrinol 26: $1646-1650$.

Oberg AL, Vitek O (2009) Statistical design of quantitative mass spectrometry-based proteomic experiments. J Proteome Res 8:2144-2156. CrossRef Medline

Obr AE, Edwards DP (2012) The biology of progesterone receptor in the normal mammary gland and in breast cancer. Mol Cell Endocrinol 357:4-17. CrossRef Medline
Paxinos G, Franklin KBJ (2004) The mouse brain in stereotaxic coordinates, Compact 2nd Edition. Boston: Elsevier Academic Press.

Pechenino AS, Frick KM (2009) The effects of acute 17beta-estradiol treatment on gene expression in the young female mouse hippocampus. Neurobiol Learn Mem 91:315-322. CrossRef Medline

Philibert RA, Sandhu HK, Hutton AM, Wang Z, Arndt S, Andreasen NC, Crowe R, Wassink TH (2001) Population-based association analyses of the HOPA12bp polymorphism for schizophrenia and hypothyroidism. Am J Med Genet 105:130-134. Medline

Pierce AA, Xu AW (2010) De novo neurogenesis in adult hypothalamus as a compensatory mechanism to regulate energy balance. $J$ Neurosci 30:723-730. CrossRef Medline

Polter A, Yang S, Zmijewska AA, van Groen T, Paik JH, Depinho RA, Peng SL, Jope RS, Li X (2009) Forkhead box, class O transcription factors in brain: regulation and behavioral manifestation. Biol Psychiatry 65:150-159. CrossRef Medline

Qin W, Pan J, Qin Y, Lee DN, Bauman WA, Cardozo C (2014) Identification of functional glucocorticoid response elements in the mouse FoxO1 promoter. Biochem Biophys Res Commun 450: 979-983. CrossRef Medline

Quadros PS, Schlueter LJ, Wagner CK (2008) Distribution of progesterone receptor immunoreactivity in the midbrain and hindbrain of postnatal rats. Dev Neurobiol 68:1378-1390. CrossRef Medline

Ren H, Plum-Morschel L, Gutierrez-Juarez R, Lu TY, Kim-Muller JY, Heinrich G, Wardlaw SL, Silver R, Accili D (2013) Blunted refeeding response and increased locomotor activity in mice lacking FoxO1 in synapsin-Cre-expressing neurons. Diabetes 62:3373-3383. CrossRef Medline

Richer JK, Jacobsen BM, Manning NG, Abel MG, Wolf DM, Horwitz KB (2002) Differential gene regulation by the two progesterone receptor isoforms in human breast cancer cells. J Biol Chem 277:5209-5218. CrossRef

Risheg H, Graham JM, Clark RD, Rogers RC, Opitz JM, Moeschler JB, Peiffer AP, May M, Joseph SM, Jones JR, Stevenson RE, Schwartz CE, Friez MJ (2007) A recurrent mutation in MED12 leading to R961W causes Opitz-Kaveggia syndrome. Nat Genet 39:451-453. CrossRef Medline

Rocha PP, Scholze M, Bleiss W, Schrewe H (2010) Med12 is essential for early mouse development and for canonical Wnt and Wnt/ PCP signaling. Development 137:2723-2731. CrossRef Medline

Rubel CA, Lanz RB, Kommagani R, Franco HL, Lydon JP, DeMayo FJ (2012) Research resource: Genome-wide profiling of progesterone receptor binding in the mouse uterus. Mol Endocrinol 26: 1428-1442. CrossRef Medline

Sanchez AM, Flamini MI, Genazzani AR, Simoncini T (2013) Effects of Progesterone and Medroxyprogesterone on actin remodeling and neuronal spine formation. Mol Endocrinol 27:693-702. CrossRef Medline

Sandstrom NJ, Williams CL (2001) Memory retention is modulated by acute estradiol and progesterone replacement. Behav Neurosci 115:384-393. Medline

Sartorius CA, Melville MY, Hovland AR, Tung LT, Takimoto GS, Horwitz KB (1994) A third transactivation function (AF3) of human progesterone receptors located in the unique $\mathrm{N}$-terminal segment of the B-isoform. Mol Endocrinol 8:1347-1360. CrossRef

Sárvári M, Kalló I, Hrabovszky E, Solymosi N, Rodolosse A, Vastagh C, Auer H, Liposits Z (2015) Hippocampal gene expression is highly responsive to estradiol replacement in middle-aged female rats. Endocrinology 156:2632-2645. CrossRef Medline

Schilling B, Rardin MJ, MacLean BX, Zawadzka AM, Frewen BE, Cusack MP, Sorensen DJ, Bereman MS, Jing E, Wu CC, Verdin E, Kahn CR, Maccoss MJ, Gibson BW (2012) Platform-independent and label-free quantitation of proteomic data using MS1 extracted ion chromatograms in skyline: application to protein acetylation and phosphorylation. Mol Cell Proteomics 11:202-214. CrossRef Medline

Schlattner U, Klaus A, Ramirez Rios S, Guzun R, Kay L, TokarskaSchlattner M (2016) Cellular compartmentation of energy metabolism: creatine kinase microcompartments and recruitment of 
B-type creatine kinase to specific subcellular sites. Amino Acids 48:1751-1774. CrossRef Medline

Schwartz CE, Tarpey PS, Lubs HA, Verloes A, May MM, Risheg $\mathrm{H}$, Friez MJ, Futreal PA, Edkins S, Teague J, Briault S, Skinner C, Bauer-Carlin A, Simensen RJ, Joseph SM, Jones JR, Gecz J, Stratton MR, Raymond FL, Stevenson RE (2007) The original Lujan syndrome family has a novel missense mutation (p.N1007S) in the MED12 gene. J Med Genet 44:472-477. CrossRef

Sellers KJ, Erli F, Raval P, Watson IA, Chen D, Srivastava DP (2015) Rapid modulation of synaptogenesis and spinogenesis by $17 \mathrm{beta}-$ estradiol in primary cortical neurons. Front Cell Neurosci 9:137. CrossRef Medline

Simons SS, Jr., Edwards DP, Kumar R (2014) Dynamic structures of nuclear hormone receptors: new promises and challenges. Mol Endocrinol 28:173-182. CrossRef

Sinchak K, Micevych PE (2001) Progesterone blockade of estrogen activation of $\mu$-opioid receptors regulates reproductive behavior. $\mathrm{J}$ Neurosci 21:5723-5729. Medline

Singh M (2006) P-mediated neuroprotection. Endocrine 29:271-274. CrossRef Medline

Skafar DF (1991) Differences in the binding mechanism of RU486 and progesterone to the progesterone receptor. Biochemistry 30 : 10829-10832. Medline

Srivastava DP, Woolfrey KM, Penzes P (2011) Analysis of dendritic spine morphology in cultured CNS neurons. J Vis Exp e2794.

Srivastava DP, Woolfrey KM, Jones KA, Shum CY, Lash LL, Swanson GT, Penzes P (2008) Rapid enhancement of two-step wiring plasticity by estrogen and NMDA receptor activity. Proc Natl Acad Sci U S A 105:14650-14655. CrossRef Medline

Srivastava DP, Woolfrey KM, Jones KA, Anderson CT, Smith KR, Russell TA, Lee H, Yasvoina MV, Wokosin DL, Ozdinler PH, Shepherd GM, Penzes P (2012) An autism-associated variant of Epac2 reveals a role for Ras/Epac2 signaling in controlling basal dendrite maintenance in mice. PLoS Biol 10:e1001350. CrossRef Medline

Stein DG, Hoffman SW (2003) Estrogen and progesterone as neuroprotective agents in the treatment of acute brain injuries. Pediatr Rehabil 6:13-22. CrossRef Medline

Su C, Cunningham RL, Rybalchenko N, Singh M (2012) Progesterone increases the release of brain-derived neurotrophic factor from glia via progesterone receptor membrane component 1 (Pgrmc1)-dependent ERK5 signaling. Endocrinology 153:43894400. CrossRef Medline

Tan H, Yi L, Rote NS, Hurd WW, Mesiano S (2012) Progesterone receptor-A and $-\mathrm{B}$ have opposite effects on proinflammatory gene expression in human myometrial cells: implications for progesterone actions in human pregnancy and parturition. $\mathrm{J}$ Clin Endocrinol Metab 97:E719-E730. CrossRef

Tetel MJ (2009) Modulation of steroid action in the central and peripheral nervous systems by nuclear receptor coactivators. Psychoneuroendocrinology 34:S9-S19.

Tetel MJ, Acharya KD (2013) Nuclear receptor coactivators: regulators of steroid action in brain and behavior. J Neuroendocrinol 25:1209-1218. CrossRef Medline

Tetel MJ, Giangrande PH, Leonhardt SA, McDonnell DP, Edwards DP (1999) Hormone-dependent interaction between the amino- and carboxyl- terminal domains of progesterone receptor in vitro and in vivo. Endocrinology 13:910-924. CrossRef

Tetel M, Jung S, Carbajo P, Ladtkow T, Skafar D, Edwards D (1997) Hinge and amino-terminal sequences contribute to solution dimerization of human progesterone receptor. Mol Endocrinol 11: 1114-1128. CrossRef Medline

Tetel MJ, Lange CA (2009) Molecular genomics of progestin actions. Hormo Brain Behav 3:1439-1465.

Uphouse L, Adams S, Miryala CS, Hassell J, Hiegel C (2013) RU486 blocks effects of allopregnanolone on the response to restraint stress. Pharmacol Biochem Behav 103:568-572. CrossRef Medline

Wagner CK (2006) The many faces of progesterone: a role in adult and developing male brain. Front Neuroendocrinol 27:340-359. CrossRef Medline

Wang X, Yang N, Uno E, Roeder RG, Guo S (2006) A subunit of the mediator complex regulates vertebrate neuronal development. Proc Natl Acad Sci USA 103:17284-17289. CrossRef Medline

Waters EM, Torres-Reveron A, McEwen BS, Milner TA (2008) Ultrastructural localization of extranuclear progestin receptors in the rat hippocampal formation. J Comp Neur 511:34-46. CrossRef Medline

Wessel L, Olbrich L, Brand-Saberi B, Theiss C (2014) New aspects of progesterone interactions with the actin cytoskeleton and neurosteroidogenesis in the cerebellum and the neuronal growth cone. J Histochem Cytochem 62:835-845. CrossRef

Woolley CS, McEwen BS (1993) Roles of estradiol and progesterone in regulation of hippocampal dendritic spine density during the estrous cycle in the rat. J Comp Neur 336:293-306. CrossRef

Xie Z, Srivastava DP, Photowala H, Kai L, Cahill ME, Woolfrey KM, Shum CY, Surmeier DJ, Penzes P (2007) Kalirin-7 controls activitydependent structural and functional plasticity of dendritic spines. Neuron 56:640-656. CrossRef Medline

Yang G, Lim CY, Li C, Xiao X, Radda GK, Li C, Cao X, Han W (2009) FoxO1 inhibits leptin regulation of pro-opiomelanocortin promoter activity by blocking STAT3 interaction with specificity protein 1. J Biol Chem 284:3719-3727. CrossRef Medline

Yang JA, Stires H, Belden WJ, Roepke TA (2017) The arcuate estrogen-regulated transcriptome: Estrogen response elementdependent and -independent signaling of ERa in female mice. Endocrinology 158:612-626.

Yore MA, Im D, Webb LK, Zhao Y, Chadwick JG, Molenda-Figueira HA, Haidacher SJ, Denner L, Tetel MJ (2010) Steroid receptor coactivator-2 expression in brain and physical associations with steroid receptors. Neuroscience 169:1017-1028. CrossRef Medline

Zhang J, Xin L, Shan B, Chen W, Xie M, Yuen D, Zhang W, Zhang Z, Lajoie GA, Ma B (2012) PEAKS DB: de novo sequencing assisted database search for sensitive and accurate peptide identification. Mol Cell Proteomics 11:M111.010587. CrossRef

Zisapel N, Levi M, Gozes I (1980) Tubulin: an integral protein of mammalian synaptic vesicle membranes. J Neurochem 34:26-32. Medline 